\title{
Restorative Justice for Multinational Corporations
}

\begin{abstract}
ANDREW BRADY SPALDING*
Deterrence theory, rooted in the methodology of law and economics, continues to dominate both the theory and practice of white-collar crime. By manipulating the disincentives of prospective wrongdoers, deterrence aims to efficiently reduce crime and maximize taxpayers' utility. However, the rise of international commerce presents a challenge it cannot meet. Using a combination of empirical evidence and quantitative modeling, this Article shows that deterrence will tend to increase, rather than decrease, net levels of corporate crime in developing countries.
\end{abstract}

The ever-increasing power of multinational corporations thus calls for a new theory of punishment, one that uses criminal enforcement to address the systemic causes of crime. That theory, quite ironically, is restorative justice. By involving the perpetrator, victim, and community in the sentencing process, restorative justice does not merely punish the wrongdoer, but remedies the harm caused by the crime, prevents future harm, and reintegrates the defendant into the very community it violated. Though generally thought to apply only to the traditional crimes of natural persons, this Article demonstrates that the U.S. Constitution and Sentencing Guidelines already authorize corporate sentencing practices rooted in restorative justice principles. More to the point, for two decades the U.S. Department of Justice has quietly been implementing restorative justice principles in domestic white-collar environmental sentencing. Drawing on those precedents, this Article builds a model for extraterritorial white-collar criminal punishment that advances the interests of U.S. corporations and enforcement agencies alike, benefits the overseas victims of corporate crime, and requires no new legal authorization to implement.

\section{TABLE OF CONTENTS}

I. INTRODUCTION

II. Deterrence Theory, Pure And Proud

A. Law and Economics' Rational Enforcement Authority

\footnotetext{
* Assistant Professor, University of Richmond School of Law. I would like to thank the following law faculties for opportunities to present prior iterations of this research: Northwestern University Law School, William \& Mary School of Law, Cardozo School of Law, and Southern Methodist University School of Law. I would also like to thank participants in the Washington \& Lee International Business Transactions workshop for their extraordinarily helpful feedback. Special thanks go to Jordan Barry, Chris Buccafusco, and Jim Gibson for their exceptionally thorough comments on earlier drafts. Finally, I am deeply grateful for the skill and dedication of my two excellent research assistants, Amanda Cottingham and Jen Wuebker.
} 


\section{B. A Case Study in Extraterritorial Deterrence: Anti-Bribery

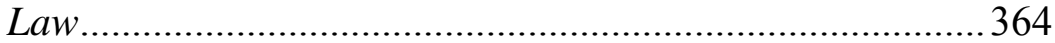

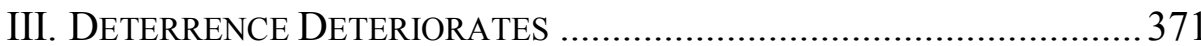

A. Subrational Governments in Inefficient Markets.................. 372

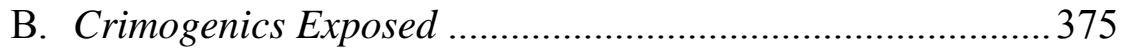

C. Am I My Brother's Utility Maximizer? ....................................381

IV. RESTORATIVE JUSTICE FOR CORPORATIONS AND THEIR

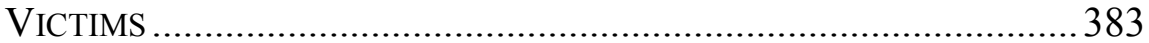

A. The Corporate Criminal as Social Healer ...............................384

B. Authorization in the U.S. Constitution ......................................392

C. Authorization in the Sentencing Guidelines........................... 397

D. A New Proposal ................................................................. 402

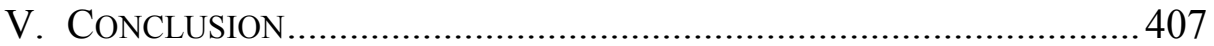

\section{INTRODUCTION}

A multinational corporation (MNC) with a U.S. nexus commits a whitecollar crime overseas. Perhaps it bribes foreign officials for business purposes, or willfully violates trade sanctions; either way, it knowingly profits from the illegal exploitation of relatively weak foreign governments. The U.S. Department of Justice imposes a criminal fine in the tens or hundreds of millions of dollars, and publicly touts the achievement. ${ }^{1}$ But where does that money go?

Those millions are deposited directly in the U.S. treasury, ${ }^{2}$ where they finance U.S. government programs and reduce the federal deficit. But the principal victims of that crime-the citizens of the government whose weakness the MNC exploited for personal gain - are scarcely helped at all. Owing to a peculiar but inherent quirk in extraterritorial white-collar criminal law, enforcement revenues accrue only to the perpetrator's public fisc.

${ }^{1}$ See, e.g., Press Release, U.S. Dep't of Justice, Alcoa World Alumina Agrees to Plead Guilty to Foreign Bribery and Pay \$223 Million in Fines and Forfeiture (Jan. 9, 2014), available at http://www.justice.gov/opa/pr/2014/January/14-crm-019.html, archived at http://perma.cc/CRQ8-CHFH ("The law does not permit companies to avoid responsibility for foreign corruption by outsourcing bribery to their agents, and, as today's prosecution demonstrates, neither will the Department of Justice." (internal quotation marks omitted)); Press Release, U.S. Dep't of Justice, Siemens AG and Three Subsidiaries Plead Guilty to Foreign Corrupt Practices Act Violations and Agree to Pay \$450 Million in Combined Criminal Fines (Dec. 15, 2008), available at http://www.justice.gov/opa/pr /2008/December/08-crm-1105.html, archived at http://perma.cc/WVV7-WEVZ ("The [government] will continue to ... ensure that the corporate and business communities are not tarnished with violations of the kind we are presenting here today." (internal quotation marks omitted)).

${ }^{2}$ See 31 U.S.C. $\S 3302$ (b) (2012). 
We may seek consolation in the doctrine of general deterrence, the supposed "holy grail" of criminal punishment. ${ }^{3}$ By this logic, though the penalty money sits in U.S. coffers, it deters prospective violators from further criminal conduct. ${ }^{4}$ The problem is that it will not work.

However effective deterrence may (or may not) be in reducing crime domestically, ${ }^{5}$ in extraterritorial white-collar enforcement it is doomed to fail: it will tend to increase net crime levels in the very countries whose social conditions we seek to improve. If our goal is to reduce crime-and it often is ${ }^{6}$ - we therefore need an alternative theory of criminal punishment; one that can better address the conditions of international commerce than deterrence ever could.

This Article provides that theory. Quite ironically, it is restorative justice: an approach to criminal punishment whereby the victims, community, and perpetrator all participate in diagnosing the causes of the criminal act, determining the appropriate punishment, and seeking the defendant's reintegration into the very community whose norms it once violated. ${ }^{7}$ And to those who may retort that restorative justice does not and could not apply to large-scale corporate crime, my answer may be surprising: it already does. The "Sentencing of Organizations" chapter of the U.S. Sentencing Guidelines (the Guidelines) ${ }^{8}$ authorizes, if not encourages, sentencing procedures founded on restorative justice principles. Moreover, federal sentencing practices do now, and have for several decades, applied those principles to a specific area of federal white-collar enforcement: domestic environmental law. ${ }^{9}$ The only remaining task is to adapt this practice to extraterritorial white-collar enforcement. ${ }^{10}$

Accordingly, Part II explains deterrence theory, its grounding in the methodology of law and economics, and its status as the dominant contemporary theory of criminal punishment. It then proposes using anti-

${ }^{3}$ Patrick J. Keenan, The New Deterrence: Crime and Policy in the Age of Globalization, 91 IOWA L. REV. 505, 515 (2006).

${ }^{4}$ See, e.g., John Bronsteen et al., Happiness and Punishment, 76 U. CHI. L. REV. 1037, 1039 (2009); Neal Kumar Katyal, Deterrence's Difficulty, 95 Мich. L. Rev. 2385, 2386 (1997); A. Mitchell Polinsky \& Steven Shavell, The Economic Theory of Public Enforcement of Law, 38 J. ECON. Literature 45, 45 (2000); George J. Stigler, The Optimum Enforcement of Laws, 78 J. POL. ECON. 526, 526 (1970).

${ }^{5}$ See, e.g., Raymond Paternoster, How Much Do We Really Know About Criminal Deterrence?, 100 J. CRIM. L. \& CRIMINOLOGY 765, 766 (2010).

${ }^{6}$ See infra Part II.B.

${ }^{7}$ See, e.g., John Braithwaite, Restorative Justice \& Responsive Regulation 11 (2002); United Nations OfFice on Drugs \& CRime, HaNdbook on Restorative Justice Programmes 6 (2006), available at http://www.unodc.org/pdf/criminal_ justice/06-56290_Ebook.pdf, archived at http://perma.cc/8FDC-3DS5.

${ }^{8}$ U.S. SENTENCING COMM’N, GUIDELINES MANUAL ch. 8 (2014).

${ }^{9}$ See infra Part IV.A.

${ }^{10}$ See infra Part IV.C. 
bribery law, particularly the U.S. Foreign Corrupt Practices Act, ${ }^{11}$ as a kind of case study in federal extraterritorial deterrence, and explains why the FCPA serves this purpose well. ${ }^{12}$ Using empirical evidence on the FCPA's impact overseas, Part III builds a model to show why deterrence will tend to fail more generally in extraterritorial white-collar enforcement. It explains the unique conditions of international business and illustrates how these conditions will often produce an increase, rather than a decrease, in overseas crime. Part IV then shows restorative justice to be a superior, if counterintuitive, paradigm for extraterritorial white-collar enforcement. It develops a new sentencing procedure that would promote the interests of the federal enforcement agencies, help the overseas victims of corporate crime, and require no new legal authorization to implement.

\section{Deterrence Theory, Pure AND Proud}

Modern deterrence theory, with its underpinnings in law and economics, posits a rational enforcement authority that manipulates the cost-benefit tradeoffs for prospective offenders to efficiently reduce crime. This section shows how the theory has remained largely unscathed despite two lines of potential criticism. It then introduces anti-bribery law as a case study in extraterritorial white-collar deterrence that illustrates deterrence's unintended and troubling consequences in foreign jurisdictions.

\section{A. Law and Economics' Rational Enforcement Authority}

The watershed work on public law enforcement in the law and economics paradigm is A. Mitchell Polinsky and Steven Shavell's The Economic Theory of the Public Enforcement of Law. ${ }^{13}$ They explain that to the law and economics way of thinking, social welfare generally is presumed to equal the sum of individuals' expected utilities. An individual's expected utility essentially depends on four variables: whether she commits a harmful act, whether she is sanctioned (by fine, imprisonment, or both), whether she is a

${ }^{11}$ Foreign Corrupt Practices Act of 1977 (FCPA), Pub. L. No. 95-213, 91 Stat. 1494, amended by Omnibus Trade and Competitiveness Act of 1988, Pub. L. No. 100-418, 102 Stat. 1107 and by International Anti-Bribery and Fair Competition Act of 1998, Pub. L. No. 105-366, 112 Stat. 3302 (codified as amended in scattered sections of 15 U.S.C.).

12 This Article is the culmination of a long-term research project exploring the impact of federal business law generally, and anti-bribery law specifically, on developing countries. Previous installments include the following: Andrew Brady Spalding, Corruption, Corporations, and the New Human Right, 91 WASH. U. L. REV. 1365 (2014) [hereinafter Spalding, Corruption]; Andrew Brady Spalding, The Irony of International Business Law: U.S. Progressivism and China's New Laissez-Faire, 59 UCLA L. REV. 354 (2011) [hereinafter Spalding, The Irony]; Andrew Brady Spalding, Unwitting Sanctions: Understanding Anti-Bribery Legislation as Economic Sanctions Against Emerging Markets, 62 FLA. L. REV. 351 (2010) [hereinafter Spalding, Unwitting Sanctions].

13 Polinsky \& Shavell, supra note 4. 
victim of someone else's harmful act, and on her tax payment (which will reflect the costs of law enforcement, less any fine revenue collected). ${ }^{14}$

The individual thus wears two hats in the utility calculation: as potential wrongdoer, and as potential victim. The potential victim's two variableswhether she is a victim and the extent of her taxes - are of course closely interconnected. Recognizing her potential victimization, she pays taxes to prevent it. The purpose of funding crime enforcement with her own taxes, then, is to prevent the disutility of victimization. The paradigm thus assumes that we pay taxes to increase our individual utility; were there no threat of victimization, the individual would have no reason to pay taxes. There'd be no utility in it; not faced with the threatened disutility of falling victim, her utility would not be maximized by paying taxes to finance public criminal law enforcement. The potential victims are taxpayers; the taxpayers are potential victims.

The "enforcement authority's problem" then is to maximize social welfare by finding the most efficient combination of the four key enforcement variables mentioned above: enforcement expenditures, the level of the fine, the length of imprisonment, and the standard for imposing liability. ${ }^{15}$ The disutility of crime is weighed against the cost of prevention, and the aim is to reduce crime with maximal cost-efficiency. The enforcement authority should expend only so much on enforcement as is necessary to reduce the disutility for the taxpayer.

Following Cesare Beccaria's admonition that it is "better to prevent crimes than to punish them," 16 law and economics seeks to deter crime by ensuring that the cost of punishment to a potential wrongdoer exceeds the rewards. ${ }^{17}$ The core assumption of deterrence is that potential wrongdoers will decide against the commission of a criminal act based on the fear of sanctions or punishment. ${ }^{18}$ It assumes that the potential (and perhaps hypothetical) wrongdoer calculates the utility of crime based on the benefits and costs of the criminal act as well as the benefits and costs of abstaining. The attributes of punishment that can be manipulated to maintain the proper cost-benefit ratio are its certainty, severity, and celerity (or swiftness). ${ }^{19}$ If set appropriately, the potential violator will succumb to deterrence because a rational choice would never result in the commission of a crime; the cost would prove too high in

\footnotetext{
${ }^{14} I d$. at 48 .

${ }^{15} \mathrm{Id}$. at $48-49$.

${ }^{16}$ See Cesare Beccaria, On Crimes and Punishments 93 (Henry Paolucci trans., Bobbs-Merrill Educ. Publ'g 1963) (1764).

${ }^{17}$ George B. Vold et Al., Theoretical Criminology 196-97 (5th ed. 2002).

${ }^{18}$ Paternoster, supra note 5, at 766.

${ }^{19} \mathrm{Id}$. at 783.
} 
comparison to the perceived benefit. ${ }^{20}$ Punishment is said to have a deterrent effect when the fear or actual imposition of punishment leads to conformity. ${ }^{21}$

The paradigm remains largely unfazed by the potential problem of criminal overdeterrence. In civil law, by contrast, the cost of overdeterrence is well-recognized: ${ }^{22}$ if the penalty for causing a car accident were \$1 million, people would cease driving. ${ }^{23}$ But for the kinds of intentional acts generally proscribed by criminal law, the risk of discouraging socially productive behavior, or of encouraging destructive behavior, is negligible. Because the goal is to achieve effective deterrence by setting punishment at a sufficiently high level to dissuade potential offenders, the "temptation to impose increasingly harsher penalties is strong." 24 The optimal level of intentional (as opposed to negligent) criminal conduct, generally speaking, is therefore zero.

But scholars have, perhaps somewhat indirectly, addressed the problem of overdeterrence in two ways. These concern the risk that deterring a particular crime might increase the incidence of other crimes. The first is the problem of marginal deterrence: setting equally high penalties for crimes of unequal severity will tend to encourage the more severe crime. As George Stigler famously put it, "If the thief has his hand cut off for taking five dollars, he had just as well take $\$ 5,000 . " 25$ Where the overall level of criminality might be understood as the number of crimes committed multiplied by their severity, disproportionate penalties for relatively mild criminal acts will remove the disincentive to engage in more serious crimes and thus increase overall levels of criminality.

The second is based on Neal Katyal's research on substitution. Katyal held that the public enforcement agency must consider how penalizing a given crime may increase the appeal of alternative, or substitute, crimes. An increase in the "price" of one crime may cause potential wrongdoers to substitute criminal act $\mathrm{X}$ with criminal act $\mathrm{Y}$ or $\mathrm{Z} .{ }^{26}$ Accordingly, though enforcing the prohibition on $X$ may well deter $X$, it may also increase the incidence of $Y$ or Z. ${ }^{27}$ For both of these problems, the effort to deter a given crime has produced

${ }^{20}$ See VOLD ET AL., supra note 17, at 196.

21 Terance D. Miethe \& Hong Lu, Punishment: A Comparative Historical PERSPECTIVE 20 (2005).

${ }^{22}$ See Richard A. Posner, Economic Analysis of LAW $\S 6.10$ (8th ed. 2011) (describing the theory of optimal tort damages). For a discussion of civil punitive damages that violate the Due Process Clause of the Fourteenth Amendment, see State Farm Mut. Auto. Ins. Co. v. Campbell, 538 U.S. 408, 416-28 (2003).

23 Bronsteen et al., supra note 4 , at 1056 n. 100 .

${ }^{24} \mathrm{Id}$. at $1055-56$. The overdeterrence problem can arise with negligence crimes; negligent vehicular homicide would raise the same overdeterrence problems as the civil example above, such that the optimal level of such homicides may be greater than zero.

25 Stigler, supra note 4 , at 527.

${ }^{26}$ Katyal, supra note 4, at 2387.

27 The enforcement authority's inclination to inflict an increasingly severe punishment may be further restrained in two ways. First, the enforcement costs must be no greater than is necessary to achieve the optimal level of deterrence. These costs would take two forms. 
the collateral harm of an increase in another form of crime. But scholarship on the substitution problem, like marginal deterrence, would hardly constitute an attack on the essential theory.

Scholars have gained somewhat more traction attacking the practice of deterrence. The core theory has given rise to a number of hypotheses that empiricists continue to test. Questions remain concerning to what extent an increase in the objective costs of punishment to a potential wrongdoer, particularly length of sentence, will decrease the incidence of crime; to what extent increasing enforcement resources will increase certainty and celerity; and whether objective increases in certainty, severity, or celerity will produce a proportional increase in the subjective perceptions of those attributes among wrongdoers and therefore exert a downward push on crime, etc. ${ }^{28}$

But note that these are questions of degree; while we do not know whether deterrence "works very well," 29 we know it works. The empirical evidence indeed demonstrates that deterrence measures succeed-however imperfectly - in reducing crime. Actors subject to the jurisdiction of a law that penalizes a given form of conduct with the requisite degree of certainty, severity, and celerity will engage in less of that conduct. We know this, and we might call it the upside of deterrence.

And notice the corollary: if we know that actors subject to a criminal prohibition will engage in less of that conduct, we also know that actors not so subject will engage in more of it. Applied to white-collar enforcement, companies subject to the criminal prohibition on a particular form of profitable but socially undesirable conduct will engage in less of that conduct than companies that are not so subject; companies not subject to that prohibition will engage, relatively speaking, in more of that conduct. This is the downside of deterrence's upside. To clarify, what I am here calling the downside is not a consequence of its upside; it is merely a logical corollary that will prove important in the analysis below. And in international business, governed by the extraterritorial application of criminal laws, where the law's stated object is to deter overseas crime, the downside proves tricky.

Most obvious are the costs of detecting, trying, and imprisoning a criminal, which are of course substantial. Bronsteen et al., supra note 4, at 1056-57. Under the logic of deterrence, they cannot become excessively so, lest the taxpayers' disutility exceeds the risk of victimization. $I d$. But additionally, society incurs the opportunity cost of removing potentially productive individuals from society through imprisonment, a factor that is (from a narrowly economic perspective) especially pronounced in white-collar crime. Id. In addition to these social costs, utilitarianism would value the welfare (though not the rights) of the defendant; he need not suffer any greater a punishment than is necessary for deterrence purposes. Id.

28 See Paternoster, supra note 5, at 787-818.

${ }^{29} \mathrm{Id}$. at 766; see DAVID M. KENNEDY, DETERRENCE AND CRIME PREVENTION: RECONSIDERING THE PROSPECT OF SANCTION 9 (2009). 


\section{B. A Case Study in Extraterritorial Deterrence: Anti-Bribery Law}

For three reasons, the Foreign Corrupt Practices $\mathrm{Act}^{30}$ is well-suited to illustrate the unanticipated consequences of extraterritorial white-collar enforcement. First, it is perhaps the clearest case of a federal statute criminalizing extraterritorial white-collar conduct that, by all indications, Congress intended as a tool for improving overseas legal institutions. I have made that argument elsewhere at some length, ${ }^{31}$ and will only summarize it briefly here.

The legislative history makes abundantly clear that Congress sought to increase transparency specifically and improve market conditions generally in developing countries through the FCPA. Congressional deliberations on the need for an extraterritorial anti-bribery statute in the 1970s were initially precipitated by the discovery that the Lockheed Corporation, the flagship U.S. defense contractor, had paid bribes to government officials in Japan, the Netherlands, and Italy to win bids. ${ }^{32}$

Each of these countries was thought critical to the growth of democratic institutions, and revelations of corporate bribery undermined liberalism's credibility. Congressman Stephen Solarz, a Democrat from New York, argued in Congress that Lockheed's payments to Japanese officials put "“[t]he democratic system in Japan ... in grave danger."'33 Opponents within Japan of that country's alliance with the U.S. were handed what he called:

[A] terribly effective weapon to drive a wedge between two close allies. At a time of uncertainty due to the shifting balances of power in Asia, our strongest and most stable ally in the region [was] undergoing unnecessary turbulence, and [a] relationship which is at the very heart of our foreign policy [was] potentially jeopardized. ${ }^{34}$

Solarz thought the "most serious" and "delicate" situation was Italy, which was "one of the keys to the southern flank of NATO" and whose government was equally split between a liberal party and the Communist Party. ${ }^{35} \mathrm{He}$ noted

${ }^{30}$ Foreign Corrupt Practices Act of 1977, Pub. L. No. 95-213, 91 Stat. 1494 (codified as amended in scattered sections of 15 U.S.C.).

${ }^{31}$ Portions of the following analysis previously appeared in Spalding, Corruption, supra note 12, at 1375-79; Spalding, Unwitting Sanctions, supra note 12, at 357-60.

32 See William D. Hartung, Prophets of War: Lockheed Martin and the MAKING OF THE MiLITARY-INDUSTRIAL COMPLEX 115-32 (2011).

33 Unlawful Corporate Payments Act of 1977: Hearings Before the Subcomm. on Consumer Prot. \& Fin. of the H. Comm. on Interstate \& Foreign Commerce, 95th Cong. 172 (1977) [hereinafter 1977 Protection Hearings] (statement of Rep. Stephen S. Solarz) (quoting "[a] very senior politician close to former [Japanese] Prime Minister Takeo Mike").

${ }^{34}$ Foreign Payments Disclosure: Hearings Before the Subcomm. on Consumer Prot. \& Fin. of the H. Comm. on Interstate \& Foreign Commerce, 94th Cong. 141 (1976) [hereinafter 1976 Protection Hearing] (statement of Rep. Stephen S. Solarz).

${ }^{35}$ Id. 
that "[a]llegations of payments by Lockheed served to advance the Communist cause in Italy where the Communist bloc was strengthened by the sight of corrupt capitalism." 36 Congress feared that the Communist Party could gain a majority in the Italian parliament and the prospects for building democratic institutions would be lost. ${ }^{37}$ The implications of corporate bribery for the U.S. effort to promote the growth of liberal institutions were thus "staggering and in some cases, perhaps irreversible." 38

The implications that Solarz feared were irreversible concerned the building of liberal economic and political institutions abroad. The institutionbuilding view of the FCPA was expressed with some poignancy by Democrat George Ball, who had become famous as a member of the Kennedy and Johnson Administrations for his opposition to the Vietnam War. Ball explained:

The vast volume of speeches, pamphlets, and advertising copy and propaganda leaflets extolling the virtues of free enterprise are cancelled every night when managements demonstrate by their conduct that a sector of multinational business activity is not free; it is bought and paid for. This is a problem that, like so many others, has relevance in the struggle of antagonistic ideologies; for, when our enterprises stoop to bribery and kickbacks, they give substance to the communist myth - already widely believed in Third World countries - that capitalism is fundamentally corrupt. $^{39}$

Continuing this theme, the Deputy Legal Adviser in the Department of State under President Ford testified that corruption "jeopardizes the important interests we share with our friends abroad" because it undermines a form of government "upon which social progress, economic justice, and perhaps, ultimately, world peace depends." 40 Treasury Secretary William E. Simon further stated that it "adversely affect[s] our relations with foreign governments and can contribute to a general deterioration in the climate for fair and open international trade and investment." 41 He feared that bribery

361977 Protection Hearings, supra note 33, at 173 (statement of Rep. Stephen S. Solarz).

371976 Protection Hearing, supra note 34, at 141.

${ }^{38}$ Id. at 2 (statement of John M. Murphy, Chairman, Subcomm. on Consumer Prot. \& Fin.).

${ }^{39}$ Foreign and Corporate Bribes: Hearings Before the S. Comm. on Banking, Hous. \& Urban Affairs, 94th Cong. 41-42 (1976) [hereinafter 1976 Senate Banking Hearings] (statement of George Ball, Senior Managing Director, Lehman Brothers).

40 The Activities of American Multinational Corporations Abroad: Hearings Before the Subcomm. on Int'l Econ. Policy of the H. Comm. on Int'l Relations, 94th Cong. 23 (1975) (statement of Mark B. Feldman, Deputy Legal Adviser, United States Department of State).

411976 Senate Banking Hearings, supra note 39, at 85 (statement of William E. Simon, Secretary, United States Department of the Treasury). Ultimately, President Ford would formally state that reports of bribery "tend to destroy confidence" in liberaldemocratic institutions. Gerald R. Ford, Special Message tO THE Congress 
would weaken, rather than strengthen, these legal and economic institutions; the statute's purpose, plainly, was to strengthen them.

Whether we sought to promote liberal legal and economic institutions overseas out of concern for those countries, or merely to advance our strategic interests, is of course debatable. But that is a question of why we should build institutions through commerce, not whether we should do so. With the integration of these themes into both the Senate ${ }^{42}$ and House ${ }^{43}$ Reports, the bipartisan consensus concerning the FCPA's intended effect becomes clear. The notion that the United States should enforce the bribery prohibition to wash our hands of overseas corruption, irrespective of its impact on overall corruption levels, was utterly absent from the deliberations. Rather, Congress envisioned a statute that would improve the conditions of foreign investment and, in turn, of global economic and political development, by promoting efficient, transparent, and relatively bribery-free institutions.

Second, the current FCPA enforcement regime is by all indications rooted in a deterrence paradigm. The enforcement agencies' principal response to findings of bribery is an investigation and a substantial fine, often in the hundreds of millions of dollars. ${ }^{44}$ Owing to their limited resources, the enforcement agencies must rely on publicizing these high-penalty actions to incentivize compliance among other prospective wrongdoers, thereby achieving a measure of general deterrence. Whether the enforcement agencies have adopted this theory of punishment consciously or not is perhaps less clear, and ultimately beside the point. The regime of selective investigation, substantial penalty, and deliberate publicizing to the broader community of similarly situated corporations is quintessential deterrence.

Third, we have empirical evidence on the impact of enforcement on capital flows into overseas markets. And that evidence raises, but does not quite answer, questions about how these capital flow changes will impact net bribery levels. Though I have likewise discussed that evidence at some length elsewhere, ${ }^{45}$ it is worth a cursory review here.

Empirical data from multiple sources demonstrate that anti-bribery enforcement causes companies subject to FCPA jurisdiction to withdraw their

Transmitting Proposed Foreign Payments Disclosure Legislation, H.R. Doc. No. 94-572, at 1 (1976). When the Carter Administration moved in, his Treasury Secretary stated, "[ $\mathrm{t}]$ he Carter Administration believes that it is damaging both to our country and to a healthy world economic system for American corporations to bribe foreign officials." Foreign Corrupt Practices and Domestic and Foreign Investment Disclosure: Hearing Before the S. Comm. on Banking, Hous. \& Urban Affairs, 95th Cong. 67 (1977) (statement of Hon. W. Michael Blumenthal, Secretary, United States Department of the Treasury).

42 S. REP. No. 95-114, at 3-4 (1977).

43 H. REP. No. 95-640, at 4-5 (1977).

${ }^{44}$ See Richard L. Cassin, Alcoa Lands 5th on Our Top Ten List, FCPA BLOG (Jan. 10, 2014, 1:08 AM), http:/www.fcpablog.com/blog/2014/1/10/alcoa-lands-5th-on-our-top-tenlist.html, archived at http://perma.cc/GHV8-PYX7 (detailing the top ten FCPA enforcement actions by penalty, ranging from $\$ 152$ million to $\$ 800$ million).

45 See Spalding, Corruption, supra note 12, at 1376-81. 
capital from developing countries. This, in turn, creates the very conditions in which bribery proliferates and illiberal regimes gain influence. Two sets of economic studies have demonstrated that anti-bribery enforcement causes corporations subject to its jurisdiction to do less business in bribery-prone markets. The first, in 1995 by James Hines, focused on the impact of the FCPA alone, finding that, controlling for other variables, FCPA enforcement caused a reduction in business in bribery-prone countries. ${ }^{46}$ To clarify, the thesis is not that U.S. companies were investing less overall in developing countries in 1995 than they were in 1976-indeed, such a conclusion would be absurd and patently unsupportable. Rather, the finding was that companies did less business in such countries than they would have if the FCPA did not exist. This initial study further found that total investment in bribery-prone countries did not drop; rather, U.S. investment was replaced by investment from countries without bribery prohibitions. ${ }^{47}$

A second set of studies conducted after enactment of the Organisation for Economic Co-operation and Development (OECD) Convention Against Bribery confirmed the finding that as anti-bribery legislation became more prevalent, bribery-prone countries received less of their foreign direct investment (FDI) from OECD nations and more from nations without bribery prohibitions. ${ }^{48}$ Professor Alvaro Cuervo-Cazurra essentially confirmed and expanded upon Hines's thesis. ${ }^{49}$ Cuervo-Cazurra's study was narrower than Hines's in that he focused exclusively on FDI, but broader in that CuervoCazurra used data on bilateral FDI inflows from 183 home economies to 106 host economies with varying quantified corruption levels. ${ }^{50}$

Cuervo-Cazurra further found that the phenomenon of businesses from countries with anti-bribery legislation investing less in highly corrupt countries

\footnotetext{
46 James R. Hines, Jr., Forbidden Payment: Foreign Bribery and American Business After 1977, at 1 (Nat'1 Bureau of Econ. Research, Working Paper No. 5266, 1995), available at http://www.nber.org/papers/w5266.pdf, archived at http://perma.cc/6577H8S4.

47 See id. at 20.

48 Alvaro Cuervo-Cazurra, Who Cares About Corruption?, 37 J. INT'L Bus. STUD. 807, 818-19 (2006).

${ }^{49} I d$. at 818 . Cuervo-Cazurra further noted that Hines's study had become subject to various methodological disputes. See id. at 808-09 (citing Shang-Jin Wei, How Taxing Is Corruption on International Investors?, 82 REV. ECON. \& STAT. 1, 2 (2000)). CuervoCazurra believed that he had improved upon Hines's methodology and yet confirmed the results. See id. Evaluating these methodologies is not the purpose of this Article. For further empirical studies confirming FCPA enforcement's negative impact on FDI, see JOHANN GRAF LAMBSDORFF, THE INSTITUTIONAL ECONOMICS OF CORRUPTION AND REFORM 174-75 (2007); Paul J. Beck et al., The Impact of the Foreign Corrupt Practices Act on US Exports, 12 MANAGERIAL \& DECISION ECON. 295, 300 (1991); Anna D'Souza, The OECD Anti-Bribery Convention: Changing the Currents of Trade, 97 J. DEV. ECON. 73, 79 (2012); Rajib Sanyal, Effect of Perception of Corruption on Outward U.S. Foreign Direct Investment, 10 GlOBAL BUS. \& ECON. REV. 123, 137 (2008).

${ }^{50}$ Cuervo-Cazurra, supra note 48 , at 811.
} 
was not limited to the United States. Rather, high levels of corruption in a host country generally resulted in less FDI from signatories to the OECD convention..$^{51}$ The same phenomenon that Hines identified with respect to the United States thus became more widespread as a result of the OECD convention. The underside of the phenomenon that Hines first identifiedcountries that are not bound by anti-bribery legislation continue to invest in corrupt countries-was likewise confirmed by Cuervo-Cazurra. Post-OECD, as signatory countries invested less in corrupt countries, countries with higher levels of corruption received relatively more FDI from countries with similarly higher corruption levels. ${ }^{52}$ The result of these trends is that as anti-bribery legislation became more widespread, corrupt countries received less of their FDI from less-corrupt countries and more of their FDI from more-corrupt countries. ${ }^{53}$

In a second empirical study, ${ }^{54}$ Cuervo-Cazurra verified and restated his finding that countries which implemented the OECD convention had become "more sensitive" to corruption and had reduced their FDI in more-corrupt countries. ${ }^{55} \mathrm{He}$ then proposed a modification of Hines's original thesis, concluding that prior to the OECD convention, U.S. investors were not in fact investing less in corrupt countries, but that they began investing less after OECD ratification. ${ }^{56}$ In other words, the FCPA standing alone did not induce U.S. investors to invest less in corrupt countries, but rather the OECD induced both U.S. and other OECD signatories to invest less. ${ }^{57}$

In addition to this empirical evidence, the historical record teaches that the U.S. Government formally embraced this very position: that FCPA enforcement reduced U.S. investment in developing countries. After the FCPA's enactment in 1977, the U.S. government began lobbying the Western world to enact a similar prohibition, ultimately succeeding in 1997 with the OECD Convention on Combating Bribery. ${ }^{58}$ In testimony before Congress, a common theme was that the U.S. business community was losing business overseas as a result of the FCPA. In his message transmitting the convention, President Bill Clinton noted that the United States "has been alone" in criminalizing overseas bribery and that "United States corporations have contended that this has put them at a significant disadvantage in competing for

${ }^{51}$ See id. at $807-08$.

52 Id. at 808.

${ }^{53} \mathrm{Id}$.

${ }^{54}$ Alvaro Cuervo-Cazurra, The Effectiveness of Laws Against Bribery Abroad, $39 \mathrm{~J}$. INT’L BUS. STUD. 634 (2008).

${ }^{55} \mathrm{Id}$. at 644 .

${ }^{56} I d$. at 645.

${ }^{57}$ See D'Souza, supra note 49 , at 85 .

58 Organisation for Economic Co-Operation and Development, Convention on Combating Bribery of Foreign Public Officials in International Business Transactions, Dec. 17, 1997, S. TREATY DOC. No. 105-43 (1998) [hereinafter OECD Anti-Bribery Convention]. 
international contracts with respect to foreign competitors who are not subject to such laws." 59 Numerous congressmen testified that the convention would "level[] the playing field," 60 as did SEC Associate Director Paul Gerlach. ${ }^{61}$ Ultimately, President Clinton would adopt this metaphor in his signing statement. ${ }^{62}$ Moreover, the Clinton Administration calculated a very specific estimate of the amount of business that U.S. corporations were losing. President Clinton indicated in his signing statement that the value of the contracts lost to U.S. businesses each year as a result of the FCPA was $\$ 30$ billion. ${ }^{63}$ The Undersecretary of State ${ }^{64}$ and the General Counsel of the Secretary of Commerce ${ }^{65}$ encompassed the same figure in their testimony. The argument proved persuasive and the U.S. joined the OECD Convention.

But the empirical studies merely confirm what common sense would teach: if we increase the costs of conducting business through the FCPA, we will tend to do less business in corrupt countries. Indeed, this sense is captured in the accumulation of anecdotal evidence in surveys and congressional testimony. A 2009 Dow Jones anti-corruption compliance survey announced in a press release entitled "Confusion About Anti-Corruption Laws Leads Companies To Abandon Expansion Initiatives," found that 51\% of companies had delayed a business initiative as a result of the FCPA and 14\% had abandoned an initiative altogether. ${ }^{66}$ More recently, a 2011 survey by the accounting firm KPMG found that among executives surveyed in the United States and the United Kingdom, "[m]ore than 70 percent . . . agreed there are places in the world where business cannot be done without engaging in bribery and corruption," and that approximately $30 \%$ of the respondents indicated that they deal with this risk by not doing business in certain countries. ${ }^{67}$

${ }^{59} \mathrm{Id}$. at III.

${ }^{60}$ E.g., The International Anti-Bribery and Fair Competition Act of 1998: Hearing Before the Subcomm. on Fin. \& Hazardous Materials, 105th Cong. 1 (1998) [hereinafter 1998 House Finance Hearing] (statement of Rep. Michael G. Oxley, Chairman, Subcomm. on Fin. \& Hazardous Materials); id. at 4 (statement of Rep. Tom Bliley, Chairman, H. Comm. on Commerce).

${ }^{61} \mathrm{Id}$. at 11 (statement of Paul V. Gerlach, Associate Director, Division of Enforcement, Securities and Exchange Commission).

${ }^{62}$ Statement on Signing the International Anti-Bribery and Fair Competition Act of 1998, 2 PUB. PAPERS 2011 (Nov. 10, 1998).

$63 \mathrm{Id}$.

${ }^{64}$ S. ReP. No. 105-19, at 45 (1998) (statement of Hon. Stuart E. Eizenstat, Under Secretary of State for Economic, Business, and Agricultural Affairs).

651998 House Finance Hearing, supra note 60, at 6 (statement of Andrew J. Pincus, General Counsel, Department of Commerce).

${ }^{66}$ See Press Release, Dow Jones, Dow Jones Survey: Confusion About AntiCorruption Laws Leads Companies to Abandon Expansion Initiatives (Dec. 9, 2009), available at $\mathrm{http}: / /$ fis.dowjones.com/risk/09survey.html, archived at $\mathrm{http}: / /$ perma.cc/Y9TS$\mathrm{R} 2 \mathrm{X} 3$.

${ }^{67}$ Mike Koehler, Survey Says..., FCPA Professor (June 2, 2011, 5:25 AM), http://fcpaprofessor.blogspot.com/2011/06/survey-says.html, archived at http://perma.cc 
This capital withdrawal, and other countries' exploitation of it, reappeared in more recent congressional testimony. During the June 2011 hearing on amending the FCPA, attorney George Terwilliger noted that while we are realizing the goal of heightened compliance with anti-bribery provisions:

[T] here is another less desirable effect... when companies forgo business opportunity out of concern for FCPA compliance risk. This hurts the creation of [U.S.] jobs and the ability of U.S. companies to compete with companies elsewhere that do not have to concern themselves with uncertainties of the terms and requirements of the FCPA.... [T] here is hidden cost borne of the uncertainties attached to FCPA compliance risk. ... [C]ompanies sometimes forgo deals they could otherwise do, take a pass on contemplated projects, or withdraw from ongoing projects and ventures. ${ }^{68}$

The label we generally attach to the government-induced withdrawal of capital from developing countries in protest of their political conditions is economic sanctions. The broader project, of which this Article is a part, analyzes the "sanctioning effect" of anti-bribery law. ${ }^{69}$ Economic sanctions literature teaches that when some part of the world sanctions a given country, a capital void is created. Because the sanctioned country still needs that capital (i.e., FDI) to stimulate its economic growth, it will look to countries not participating in the sanctions to fill the void. These latter countries are sometimes called "black knights"- they rescue the sanctioned country, but through nefarious means. ${ }^{70}$

Anti-corruption law is today creating a similar sanctioning effect, as the empirical evidence above concerning "ownership substitution" and the survey data demonstrate. The principal black knight in the anti-bribery space is China - a country with ample capital, an aggressive foreign and economic policy, and a near-complete absence of extraterritorial anti-corruption enforcement. ${ }^{71}$ When companies subject to U.S. jurisdiction find the risk of a bribery violation too high, and they withdraw from a project, or a sector, or a country, the resulting FDI void is frequently filled by Chinese or other "black knight" companies who are not subject to extraterritorial anti-bribery enforcement.

But what effect does this dynamic have on our deterrence goals? What is the net impact on the overall rates of bribery, for example, in the host country?

/V89T-U82Q (quoting KPMG, GLOBAL ANTI-BRIBERY AND CORRUPTION SURVEY 2011, at 18 (2011)).

${ }^{68}$ Foreign Corrupt Practices Act: Hearing Before the H. Subcomm. on Crime, Terrorism, \& Homeland Sec. of the H. Comm. on the Judiciary, 112th Cong. 37 (2011) (statement of George J. Terwilliger, III, Partner, White \& Case LLP).

${ }^{69}$ See Spalding, The Irony, supra note 12, at 402-03; Spalding, Unwitting Sanctions, supra note 12, at 372-73. Portions of Parts I.A and I.B have been adapted from material that previously appeared in one or more of those Articles.

70 See Spalding, Unwitting Sanctions, supra note 12, at 397.

${ }^{71}$ See Spalding, The Irony, supra note 12, at 360-61. 
The empirical evidence does not address this question. The next section builds a model to do so.

\section{DETERRENCE DETERIORATES}

This section illustrates how extraterritorial deterrence will ultimately fail to deliver on its promise of efficiently protecting prospective victims from crime. Using empirical evidence, it builds a quantitative model to demonstrate the impact of anti-bribery enforcement on overall levels of bribery in a host country. Our deterrence efforts ultimately prove to be neither effective nor efficient: we cannot reduce crime, and may even increase crime; and we cannot justify this, or any other result, to those taxpayers who seek utility maximization through cost efficiency.

Though scholars up to now have not seemed particularly concerned about the collateral economic harm of deterring criminal behavior, contemporary international white-collar enforcement presents new challenges to the logic of deterrence. Despite deterrence's relatively long history, originating in the eighteenth-century works of Montesquieu, ${ }^{72}$ Beccaria, ${ }^{73}$ and Bentham, ${ }^{74}$ the concept fell out of fashion and was largely neglected ${ }^{75}$ until the seminal work of Gary Becker in the 1960s. ${ }^{76}$ And owing largely to Cold War ideological divisions, international business - and particularly the flow of capital from developed to developing countries-would not increase significantly until after the collapse of communism in the early 1990s. As will be shown below, this new economic order raises significant theoretical and practical problems for deterrence.

Extraterritorial conduct of any sort already raises formidable law enforcement challenges: evidence is difficult to collect, foreign enforcement authorities may not be cooperative or well resourced, and cultural sensitivities must be navigated. But this Article argues that the challenges of extraterritorial white-collar deterrence run far deeper. By definition, many or most actors committing crimes in foreign jurisdictions are not subject to the same set of disincentives: companies seeking to extract Nigeria's oil will hail from the United States, the European Union, Russia, China, and elsewhere, and these countries will have substantially different white-collar crime regimes in place. The United States, for example, may be able to deter socially destructive behavior among U.S. companies and other companies subject to U.S. jurisdiction, but it cannot readily alter the behavior of those companies that lie

\footnotetext{
72 MonTESQuieu, THE SPIRIT OF THE LAWS 161-62 (David Wallace Carrithers ed., Thomas Nugent trans., Univ. of Cal. Press 1977) (1748).

73 BECCARIA, supra note 16.

${ }^{74}$ Jeremy Bentham, AN Introduction to the Principles of Morals AND LEGISLATION 170-71 (1965).

${ }^{75}$ See Paternoster, supra note 5, at 773.

76 See, e.g., Gary S. Becker, Crime and Punishment: An Economic Approach, 76 J. POL. ECON. 169, 170 (1968).
} 
beyond its jurisdiction. To the extent that a country wishes to reduce criminal conduct in overseas locations where only a portion of all actors is subject to its jurisdiction, this becomes problematic.

Of course, it may well be true that in certain areas of law the aim is not to reduce the overall levels of a given sort of extraterritorial crime. We may wish only to deter the conduct among our own citizens, perhaps untroubled by the impact our own deterrence efforts may have on overall levels of criminality in those foreign locations. But other areas of law, such as anti-bribery law, prohibit the overseas conduct categorically, without regard to whether the conduct has any harmful impact whatsoever on U.S. markets or persons. This section shows just how problematic that goal will prove to be. It develops a model ${ }^{77}$ that illustrates how, given current and foreseeable future legal and economic conditions, extraterritorial deterrence has pronounced crimogenic ${ }^{78}$ tendencies. That is, in attempting to reduce crime overseas, wielding the tools of deterrence will often create the conditions in which the conduct we seek to deter actually proliferates.

In building the model, this Article will not speculate on how a perfectly rational government might enforce a bribery prohibition. Rather, it seeks to understand how actual governments, subject to constraints in their knowledge and other resources, do enforce such laws. Part III.A explains the various assumptions that are necessary if the subsequent model is to mimic reality to any meaningful degree. Part III.B then builds that model, and Part III.C draws out the implications that pose particular problems for utilitarianism.

\section{A. Subrational Governments in Inefficient Markets}

FDI, particularly in developing countries, has three inherent characteristics that distinguish it from the domestic conduct that deterrence scholarship generally assumes. In combination, they create a kind of perfect storm in which deterrence will often prove self-defeating.

The first I will call selective criminalization. A given form of extraterritorial conduct may well be criminalized by a particular home jurisdiction: think of express statutory prohibitions on overseas bribery or monopolistic conduct in the United States, and the dedication of substantial resources to their enforcement. But other countries may fall into either of two alternative categories: those that do not enforce their prohibitions, and those

${ }^{77}$ This model was first presented in a Chapman University School of Law Symposium entitled, What Can Law and Economics Teach Us About Corporate Social Responsibility? An earlier version of this model has been published. See generally Andrew Spalding, The Problem of Deterring Extraterritorial White-Collar Crime, 17 CHAP. L. REV 355 (2014).

${ }^{78}$ For discussion of crimogenics in deterrence, see Paul H. Robinson \& John M. Darley, The Role of Deterrence in the Formulation of Criminal Law Rules: At Its Worst When Doing Its Best, 91 GEO. L.J. 949, 985 (2003); see also KENNEDY, supra note 29, at 54-72. 
that have not enacted such prohibitions. In other words, among all actors in a given foreign jurisdiction, the conduct is only selectively criminalized: the criminal prohibition applies to some of the companies pursuing Nigerian oil, but not to others. The United States may wish to deter bribery there, but lacks jurisdiction over many of the actors.

The second characteristic I will call the discretionary investment forum. A typical U.S.-based company will be doing business in the United States. The enforcement authority thus need not worry whether that company will choose to continue doing business there (unless, of course, a given criminal prohibition threatens to drive a company out of business altogether, but this is rare and probably confined to highly dubious business models). But overseas investment forums are inherently discretionary: a U.S.-based company may choose to focus its efforts in the United States, or to enter overseas markets, and if the latter, whether to focus on the developed or developing world, and whether to invest in particular countries. These countries will vary in their legal, economic, and cultural environments, potentially creating varying levels of risk that a U.S.-based company will engage in conduct that its home jurisdiction criminalizes. Accordingly, the enforcement authority must consider whether its companies will do business in these jurisdictions at all. When the enforcement authority uses the tools of deterrence to raise the costs of particular behavior, the costs may rise to the level that, in certain contexts, the risk becomes too great. Companies may then use their discretion to not invest in particular projects, sectors, or countries. The effort to deter crime has thus deterred investment.

Should the enforcement authority care? The question goes to the very heart of the law and economics methodology. Richard Posner has characterized law as "a system for maximizing the wealth of society." 79 The aim of enforcement is thus to increase wealth, for individual persons and for society generally. The deterrence of investment in foreign countries has implications for both. Companies may forego relatively efficient investment opportunities for safer, but less efficient (and profitable) opportunities. This, in turn, impacts the wealth of both the capital-exporting and the capital-importing nation: the exporter's GDP is negatively impacted by the diminished profits of its companies; and the importer's GDP is negatively impacted by the loss of foreign direct investment. If deterrence is understood as one of many mechanisms for increasing social wealth, deterring investment in particular discretionary investment forums is problematic. This becomes especially true in developing countries where the need to maximize wealth is most pressing.

The third characteristic I will call investor substitution, and it is alluded to in the empirical studies mentioned above. Assume, for purposes of this theory, that the companies from diverse jurisdictions are interchangeable-that companies from the United States, Germany, and China are equally capable of providing the given good or service. This is of course not true in all industries;

\footnotetext{
${ }^{79}$ POSNER, supra note $22, \S 2.2$.
} 
highly technologically sophisticated sectors, for example, will tend to favor companies from more developed countries. But the gap is narrowing as developing countries like China progress, and the gap does not exist at all for many or most industries. Further assume that the host country's need for FDI is constant, such that if companies originating from one jurisdiction are disinclined to do business in the manner expected by the host country, that host country will seek the investment from other jurisdictions. Given these assumptions, quasi-criminalization and the discretionary investment forum will result in investor substitution. Companies from a country that enforces a given criminal prohibition-again, think of the United States enforcing a bribery prohibition - may find the risk (say, of paying bribes in Nigeria) too high. Those companies may choose not to invest in countries like Nigeria (as ample empirical evidence demonstrates). ${ }^{80}$ The host country, which remains in need of the FDI, will seek it from companies that are from jurisdictions that do not enforce the prohibition. Because these companies can provide roughly the same good or service - in other words, the substitution costs to the host country are negligible - they will become substitute foreign investors.

This analysis is related to, but significantly different from, the previous work on substitution. That body of scholarship, as noted above, has focused on a given actor substituting criminal acts $\mathrm{Y}$ and $\mathrm{Z}$ for criminal act $\mathrm{X}$. It assumed a given set of actors, choosing among alternative forms of criminality. The principle of investor substitution is quite different. It assumes alternative actors all deciding whether to engage in the same form of criminality (or, to be clear, conduct that one jurisdiction deems criminal, though others do not). It is a variation on the substitution thesis that applies uniquely to the realm of extraterritorial enforcement.

While these conditions characterize the business environment that governments try to regulate, a second set of conditions will describe how governments might go about that regulation. This Article does not assume the existence of a perfectly rational enforcement authority. Rather than exploring what a hypothetical authority should do, it explores the implications of what actual governments would do or have done. It posits a number of conditions that closely resemble the actual world of anti-bribery enforcement, conditions which would likely be typical of other areas of extraterritorial white-collar criminal enforcement as well. Such an enforcement authority is, predictably, economically subrational in several important respects.

First, the enforcement authority assumes that the optimal level of bribery is zero, and does not engage in sophisticated arguments about whether some amount of bribery may actually be efficient. This assumption holds true both for bribery among companies subject to its jurisdiction and for overall levels of bribery in the host countries as well. Alternatively, one might assume that the enforcement authority is guided by a deontological argument - that bribery

${ }^{80}$ For a summary of the empirical literature, see Spalding, Corruption, supra note 12, at $1375-79$. 
is inherently wrong - rather than an assumption about the relationship between bribery and economic efficiency. Either way, the authority is determined to reduce bribery as far as possible.

Second, and relatedly, the agencies of the enforcement authority that enforce the bribery prohibition will actually take measures to deter bribery without regard for their impact on economic efficiency. Whatever they may have assumed about the relationship between bribery and efficiency, the statute charges the agencies with reducing bribery and makes no mention of its economic implications.

Third, the enforcement authority is unwilling or unable to impose a combination of enforcement expenditures and level of penalty that would immediately reduce bribery to zero. It is faced with limited enforcement resources, uncertain political support, and imperfect empirical knowledge about the effects of enforcement on crime. Similarly, it likely subscribes to notions of fairness that will prevent it from imposing the exorbitant penalties that could deter bribery where the probability of detection was more limited. Thus constrained, the enforcement authority experiments with varying levels of enforcement over time (which is precisely what has occurred in the United States). ${ }^{81}$ Accordingly, the illustration below posits a recognizably subrational enforcement authority, and uses law and economics principles to trace out the implications of that authority's enforcement decisions.

\section{B. Crimogenics Exposed}

Assume, then, a developing country (the host country) that solicits foreign direct investment in its infrastructure sector. In this country and sector, bribery is quite common. Further assume that companies from two jurisdictionsJurisdiction A and Jurisdiction B-have historically invested in this sector. ${ }^{82}$ All firms competing in the host country's infrastructure sector are from one of these jurisdictions; no companies from jurisdictions other than A or B are investing there.

The host country will regularly issue requests for proposals (RFPs) and companies will submit bids in an effort to win contracts. Each contract involves a variety of transactions in which bribes would typically be paid: some would be paid during the bidding process (preparing and submitting the bid, then winning the contract) and others would be paid in the course of performing the contract (visas, permits, inspections, etc.). Further assume that the number of transactions per contract is fixed, resulting in a fixed number of

\footnotetext{
81 See id. at $1371-75$.

82 I use "jurisdiction" rather than "country" because often the jurisdiction of a given country will extend to companies from other countries as well-for example, certain foreign companies are subject to the jurisdiction of the U.S. extraterritorial anti-bribery statute, such that even though they do not reside in the United States, they are nevertheless "from" the U.S. jurisdiction.
} 
total transactions. For purposes of this argument, assume that $100 \%$ of all business transactions in the host country's government have involved bribes.

At a time that we shall call Time 1, neither Jurisdiction A nor Jurisdiction $\mathrm{B}$ is enforcing an extraterritorial bribery prohibition. Firms from both A and B therefore pay bribes freely. But Jurisdiction A firms are more efficient than Jurisdiction B firms, such that A firms in Time 1 win $60 \%$ of the contracts and B firms win $40 \%$. The chart below captures these numbers.

Table 1

\begin{tabular}{|c|c|c|c|c|}
\hline Time & $\begin{array}{c}\text { Enforcement } \\
\text { Level }\end{array}$ & $\begin{array}{c}\text { \% Market } \\
\text { Share for } \\
\text { Firms from } \\
\text { Jurisdiction A }\end{array}$ & $\begin{array}{c}\text { \% Bribes That } \\
\text { A Firms Pay } \\
\text { in Their } \\
\text { Transactions }\end{array}$ & $\begin{array}{c}\text { Overall Rate } \\
\text { of Bribery in } \\
\text { Host } \\
\text { Country }\end{array}$ \\
\hline T1 & None & 60 & 100 & 100 \\
\hline
\end{tabular}

Firms from Jurisdiction A win $60 \%$ of the contracts, but pay bribes in $100 \%$ of the transactions. Jurisdiction B firms thus have a $40 \%$ market share, and likewise bribe $100 \%$ of the time. The overall rate of bribery in the infrastructure sector of the host country is therefore $100 \%$ in Time 1 .

However, at Time 2, Jurisdiction A announces that it will begin enforcing an extraterritorial criminal bribery prohibition. The enforcement agencies are, again, subrational actors, so they are unable to implement an enforcement regime that would reduce bribery to zero: they cannot dedicate the resources necessary to raise the probability of detection to the requisite level, and fairness principles do not allow them to impose exorbitant penalties that would compensate for the low level of detection. Constrained as they are by limited resources and by fairness, they commence what we will call a low level of enforcement. Jurisdiction B does not follow suit and does not implement any kind of extraterritorial bribery prohibition, so B firms continue to bribe freely.

The host country issues a new set of RFPs and awards all available contracts to firms from Jurisdictions A and B. A firms now become what we will call reluctant bribe payers. They do not stop paying bribes altogether, but they begin searching for ways to avoid paying bribes where possible while remaining present in the sector and profitable. While they may have previously paid a small bribe to expedite a visa approval, they are now willing to wait; instead of paying a bribe to send their goods immediately through customs, their ships wait in line for days in the harbor. Similarly, the government of Jurisdiction A begins working on behalf of its companies to reduce the demand for bribery in the host country (as the U.S. and U.K. governments do today).

The reluctant bribe payers (companies from Jurisdiction A) recognize that avoiding bribes will often reduce their efficiency-waiting in the harbor for customs approval is not without cost to the company. But they are willing to absorb these costs to reduce the risk of penalty for violating the prohibition. 
Although the risk of penalty is high enough to deter a certain amount of bribery, it is not high enough to completely stop paying bribes. For reluctant bribe payers, the benefits of continuing to invest in the host country remain high enough that the company can pay some bribes and accept the risk that it will be caught and penalized for violating the bribery prohibition.

In the course of continuing to do business in the host country, the reluctant bribe payer will therefore encounter three kinds of transactions. The first is where the risk of detection is sufficiently high (or the firm is sufficiently principled) that it refuses to pay the bribe but can still find ways to complete the transaction. These may entail increased costs for the firm (such as waiting in line at port) but owing to the firm's efficiency (or the less than perfectly competitive market conditions) the firm can absorb these costs while remaining profitable. Alternatively, the firm may seek the diplomatic assistance of the governments (in the United States, these would be the Departments of Commerce or State). This is the kind of conduct that antibribery advocates seek to incentivize and may generally assume occurs. However, the firm will encounter a second kind of bribe, in which it will likewise refuse to pay but cannot complete the transaction without it. The firm must therefore knowingly forego the transaction; the best example would be a lost bid in a RFP. For the third kind of bribe, the risk of detection may be sufficiently low, or the costs of foregoing the transaction are sufficiently high (the company really needs this particular bid, or cannot afford to wait three days in port) that the firm will pay the bribe and accept the risk of detection. ${ }^{83}$

Given the three types of bribes the firm will encounter and Jurisdiction A's new but still-low level of enforcement, assume that A firms reduce their bribery by half. They are now willing pay bribes in $50 \%$ of all transactions. Assume further that as a result, the percentage of contracts they will be able to win also drops by half, from $60 \%$ of all contracts to $30 \%$ of all contracts. Investor substitution occurs, and B firms win the extra $30 \%$ of the contracts. Now A firms have $30 \%$ of the market and B firms have $70 \%$. Owing to the downside of deterrence's upside, B firms continue to bribe in $100 \%$ of all their transactions, and therefore will bribe on the extra $30 \%$ of the contracts they will win. But because A firms were paying bribes on those contracts in Time 1 , investor substitution has not resulted in a net increase in bribery in the host country.

${ }^{83}$ The ability of companies from Jurisdiction A to absorb a degree of lost profits but remain competitive assumes that the market is not what economists would consider perfectly competitive. If it was, the companies would have no margin to absorb the losses because competitors would have already been selling at the lower cost. But foreign direct investment is not perfectly competitive, in at least two respects. First, often a sort of oligopoly exists where only select companies from select countries are positioned to compete. Second, some companies might have a competitive advantage by virtue of their access to capital, technological, or various forms of government support. Accordingly, this illustration assumes that Jurisdiction A firms are operating at a level of profitability that permits them to absorb limited losses to comply with the statute. 
Rather, A's low level of enforcement has thus succeeded in two respects. Of the $30 \%$ of the contracts that A firms win, they will only pay bribes in $50 \%$ of these transactions. For half of this $30 \%$, or $15 \%$, no bribes are being paid; this portion of the host country's infrastructure sector is now clean. A's enforcement has thus reduced bribery among its own firms by $50 \%$, and has reduced net bribery levels in the host country by $15 \%$.

Table 2

\begin{tabular}{|c|c|c|c|c|}
\hline Time & $\begin{array}{c}\text { Enforcement } \\
\text { Level }\end{array}$ & $\begin{array}{c}\text { \% Market } \\
\text { Share for } \\
\text { Firms from } \\
\text { Jurisdiction A }\end{array}$ & $\begin{array}{c}\text { \% Bribes } \\
\text { That A Firms } \\
\text { Pay in Their } \\
\text { Transactions }\end{array}$ & $\begin{array}{c}\text { Overall Rate } \\
\text { of Bribery } \\
\text { in Host } \\
\text { Country }\end{array}$ \\
\hline T1 & None & 60 & 100 & 100 \\
\hline T2 & Low & 30 & 50 & 85 \\
\hline
\end{tabular}

Again, overall levels of bribery have gone down from $100 \%$ to $85 \%$ because A firms have a 30\% market share and are not paying bribes on half of the related transactions. This is the outcome that anti-bribery advocates take for granted, and for those who accept the normative premise that federal law should deter overseas bribery, it is the reason to continue enforcement.

But now assume a subsequent point in time, called Time 3 . The enforcement authorities in Jurisdiction A, perhaps encouraged from the successes of Time 2, have decided to ramp up enforcement through the dedication of new resources. We will call this mid-level enforcement, and it significantly increases the likelihood of detecting violations. In Time 3, the host country issues a new set of RFPs. The other assumptions still hold: the total number of transactions is again fixed, companies from Jurisdictions A and B will again compete, and companies from Jurisdiction B still bribe without fear of punishment.

Companies from Jurisdiction A now engage in a new cost-benefit analysis. They conclude that because the risk of detection and therefore penalty is higher, they must pay even fewer bribes than they did in Time 2. Say that midlevel enforcement induces A firms to reduce their bribery percentage from $50 \%$ to $25 \%$ of all transactions.

The mid-level enforcement regime has thus succeeded in reducing bribery among companies subject to its jurisdiction. But consider the impact that investor substitution will now have on the change in overall bribery levels from Time 2 to Time 3. Although A firms won $60 \%$ of all contracts when bribing $100 \%$ of the time, they can now win only $1 / 4$ of those contracts. ${ }^{84}$

${ }^{84}$ This exercise assumes that the percentage of contracts it can win will drop in precisely the same amount as the percentage of bribes it can pay. In practice, the relationship between these two figures would be more complex. 
They now have only a $15 \%$ market share, down from $30 \%$ in Time 2 . The $15 \%$ market share that A firms have lost since Time 2 will now go to B firms, which continue to bribe $100 \%$ of the time. In other words, $15 \%$ of the transactions have shifted from reluctant bribe payers to free bribe payers. A firms remain engaged in only $15 \%$ of all transactions in the host country's infrastructure sector, and they will pay bribes in $1 / 4$ of that $15 \%$. Accordingly, A firms are bribe-free in $11 \%$ of all transactions. Because all other transactions are paid with bribes, the overall bribery level in the host country is now at $89 \%$.

Table 3

\begin{tabular}{|c|c|c|c|c|}
\hline Time & $\begin{array}{c}\text { Enforcement } \\
\text { Level }\end{array}$ & $\begin{array}{c}\text { \% Market } \\
\text { Share for } \\
\text { Firms from } \\
\text { Jurisdiction A }\end{array}$ & $\begin{array}{c}\text { \% Bribes That } \\
\text { A Firms Pay } \\
\text { in Their } \\
\text { Transactions }\end{array}$ & $\begin{array}{c}\text { Overall Rate } \\
\text { of Bribery in } \\
\text { Host Country }\end{array}$ \\
\hline T1 & None & 60 & 100 & 100 \\
\hline T2 & Low & 30 & 50 & 85 \\
\hline T3 & Mid & 15 & 25 & 89 \\
\hline
\end{tabular}

From Time 2, overall bribery has increased by $4 \%$. And that increase is entirely due to Jurisdiction A's increased enforcement effort.

Consider a further period in time, Time 4, in which Jurisdiction A has finally resolved to dedicate the enforcement resources necessary to achieve what it deems the optimal rate of bribery among its firms - $0 \%$. And suppose it succeeds, such that now A firms pay absolutely no bribes. Further assume that all other conditions remain the same, and the host country issues a new set of RFPs. Jurisdiction A firms can no longer win contracts in this host country's infrastructure sector. B firms now win 100\% of the contracts, engage in $100 \%$ of the transactions, and pay bribes $100 \%$ of the time. While the rate of bribery among A firms is now $0 \%$, the overall rate of bribery in the host country is $100 \%$. 
Table 4

\begin{tabular}{|c|c|c|c|c|}
\hline Time & $\begin{array}{c}\text { Enforcement } \\
\text { Level }\end{array}$ & $\begin{array}{c}\text { \% Market } \\
\text { Share for } \\
\text { Firms from } \\
\text { Jurisdiction A }\end{array}$ & $\begin{array}{c}\text { \% Bribes That } \\
\text { A Firms Pay } \\
\text { in Their } \\
\text { Transactions }\end{array}$ & $\begin{array}{c}\text { Overall Rate } \\
\text { of Bribery in } \\
\text { Host } \\
\text { Country }\end{array}$ \\
\hline T1 & None & 60 & 100 & 100 \\
\hline T2 & Low & 30 & 50 & 85 \\
\hline T3 & Mid & 15 & 25 & 89 \\
\hline T4 & High & 0 & 0 & 100 \\
\hline
\end{tabular}

Notice the pattern. At Time 2, its efforts to deter bribery were effective in reducing the overall level of bribery in the host country. Companies from Jurisdiction A indeed lost business as a result of the decision to enforce the bribery prohibition. But in Time 1, companies from Jurisdiction A were bribing as freely as companies from Jurisdiction B, so losing business to companies from Jurisdiction B at Time 2 did not result in an increase in bribery for the host country. Then at Time 3, the second increase in enforcement has reduced bribery only among companies subject to A's jurisdiction. Those companies are indeed bribing less, but owing to investor substitution, the impact on overall levels of bribery in the host country is a net increase. And we saw at Time 4 that raising penalty risks further can produce a scenario in which the rates of bribery in the host country return to $100 \%$, a level not seen since before the enforcement effort began.

In sum, after Time 1, the overall rate of bribery in the host country correlates inversely with Jurisdiction A's enforcement. Likewise, it correlates inversely with the percentage of bribes that A firms are paying. As Jurisdiction A attempts, and succeeds, in decreasing bribery among its own companies, it increases overall bribery in the developing country.

This illustration is of course artificially simplified. In reality, a number of additional variables would influence the net impact of increased enforcement: the number of transactions, the number of agencies or persons soliciting bribes, changes in the level of penalty, changes in the effectiveness of the reluctant bribe payer's tools for avoiding bribes, and perhaps most importantly, a decrease in the percentage of transactions in developing countries that require bribes. Expanding this model to include each of these variables is a project for another day. But this thought experiment nevertheless illustrates limitations inherent in the effort to deter extraterritorial white-collar crime, given current global economic and legal conditions. And it raises two distinct utilitarian problems. 


\section{Am I My Brother's Utility Maximizer?}

Though the enforcement authority's aim is to maximize utility, extraterritorial white-collar deterrence will tend to produce two distinct forms of disutility.

The first is, quite simply, that it often will not work. As explained above, overseas business environments will often produce an increase, rather than a decrease, in the conduct we seek to deter. This will be true as long as capitalexporting jurisdictions vary in their enactment and enforcement of criminal prohibitions. The answer, one might think, is to tinker with the variables available to the enforcement authority: enforcement expenditures, fine levels, the length of imprisonment, and the standard for imposing liability. The problem, however, is that once into Time 2, decreasing the cost of the penalty through any of these four variables will necessarily decrease the disincentive to engage in the act: reducing enforcement expenditures, fines, or prison terms, or raising the standard for imposing liability, will decrease the costs of crime and increase its frequency.

In Times 2 and 3, the enforcement authority is trapped. By not increasing the risk of detection, it tolerates a measure of criminality among persons subject to its jurisdiction. But by raising the risk of detection, it produces the concurrent decrease in criminality among its companies, and an increase in that same behavior in the host country among all actors. These are the Scylla and Charybdis of extraterritorial white-collar criminal enforcement. The enforcement authority must choose between the harm of knowingly tolerating preventable criminality among its own companies, and knowingly increasing levels of criminality in vulnerable developing countries. It cannot avoid both.

The enforcement authority thus seeks the golden mean or, if one prefers, the Goldilocks theory, of enforcement: to enforce its prohibition only to the point that it deters overall levels of bribery, and not further. The law and economics enforcement authority is trapped in this dilemma, unable to achieve what it considers the optimal level of criminality among its own actors without raising levels of the same conduct in the host country.

But even if the first problem were resolved, and overseas deterrence efforts were to effectively reduce crime, the law and economics enforcement authority would be left with a second problem. Consider again the assumption behind the economic theory of public enforcement: the taxpayer is the potential victim, and she pays taxes to prevent her victimization. That works in domestic enforcement, where all potential victims are taxpayers and all taxpayers are potential victims. But what if the victims are not taxpayers, and the taxpayers are not victims? What if the victims lie beyond the jurisdiction that is enforcing the criminal prohibition, and are therefore not paying the taxes that fund enforcement? Put another way, am I my brother's utility maximizer?

Again using the anti-bribery example, we devote substantial public resources to protecting those overseas victims through the DOJ, SEC, FBI, 
offices in Commerce and State, and the federal judiciary. ${ }^{85}$ And various economic benefits might very well accrue to U.S. taxpayers, including the improvement of overseas markets and the resulting potential for economic and political alliances. But stakeholders to anti-bribery enforcement generally agree that the principal victims of extraterritorial bribery are the citizens of the overseas governments. And they're not paying for enforcement. That is, Congress enacted a statute in which U.S. taxpayers would pay to protect nontaxpayers from the harms of bribery. To the utility-maximizing taxpayer typically associated with law and economics, this is the second disutility of deterrence. It is inescapable, and reflects the limitations of the deterrence paradigm in explaining not just how to deter overseas criminality, but why we should even try.

To the extent that the extraterritorial statute is designed both to deter criminality among the jurisdiction's own actors and to reduce overall levels of crime, the traditional mechanisms of deterrence may not be the most effective tools available. That is, the means typically employed by deterrence advocates may not be best suited to achieve deterrence's goals. Rather, the achievement of deterrence goals may require using non-deterrence, or extra-deterrence, means.

As the above illustration shows, extraterritorial crime reduction requires reaching two sets of actors who lie beyond the reach of the enforcement authority. The first is the host country: to the extent that a capital-importing country can enforce its own prohibitions (on bribery, for instance) no investor substitution can occur. All companies investing in that country would (in theory) be subject to the same risks and costs, and would engage in crime at roughly similar levels. If the host country sought to reduce a given form of conduct to zero, it could do so, and differences among the capital-exporting jurisdictions would become irrelevant. But a developing country, almost by definition, is ill-equipped to do so; its state is not yet sufficiently resourced to deter the conduct of powerful foreign firms. This is thus a long-term project. Accordingly, the capital-exporting jurisdiction seeking to deter destructive conduct in foreign countries can also seek to influence the behavior of competing capital-exporting jurisdictions that do not enforce comparable prohibitions (the B Jurisdictions). The problem, of course, is that the enforcing jurisdictions (the A Jurisdictions) generally have no authority over either the capital-importing or capital-exporting governments.

But notice the relatively modest - and therefore perhaps not intractableproblem. At Time 3, when the overall rates of bribery in this model increased for the first time, the difference was relatively slight: a mere 4\%. At Time 4, when the enforcing jurisdiction resolved to achieve the optimal level of

85 See U.S. Dep'T of Justice \& U.S. SEC. \& EXCh. COMM'N, A RESOURCE Guide to THE U.S. ForeIGN CORRUPT PRACTICES ACT 4-7 (2012) [hereinafter RESOURCE GuIDE], available at http://www.justice.gov/criminal/fraud/fcpa/guide.pdf, archived at http://perma.cc/V86D-N7QQ. 
bribery among its companies (namely, none) the overall level increased by another $11 \%$.

These numbers are not staggering. But when the policy aim is crime reduction in the host country, any crime increase that results directly from our enforcement efforts merits some attention. Admittedly, criminal enforcement would unleash other forces that would chip away at this increase, particularly where the enforcement actions are publicized. Civil society can agitate for reforms. Other states can wield the levers of international diplomacy. International organizations can pressure non-enforcing jurisdictions through review mechanisms. These forces are significant, and this analysis does not mean to dismiss them. But acknowledging a perverse enforcement outcome, and merely hoping that other entities or policy initiatives will reverse it, is hardly satisfactory. This Article aims to identify an approach to criminal enforcement that would itself achieve the stated aim of reducing crime. The next section does so.

\section{RESTORATIVE JUSTICE FOR CORPORATIONS AND THEIR VICTIMS}

As the above model illustrates, the deterrence approach suffers from two distinct but closely related limitations that in combination prove fatal. First, it cannot reach competitor firms from jurisdictions that do not enforce the extraterritorial prohibition. Extraterritorial deterrence fails because not all potential violators are subject to the enforcing country's jurisdiction. But this is not the only way to approach crime reduction in a foreign jurisdiction. The other would be to adopt host-country reforms that could reduce the environmental inducements (such as bribe solicitation or extortion) that give rise to crime. We might use criminal enforcement to identify the causes of crime and to identify or fund initiatives to address those causes. But the lawand-economics approach to deterrence undertakes no such thing; it does not even try to reach the host country governments. It merely punishes the wrongdoer, with the aim of specifically deterring the wrongdoer's recidivism and generally deterring others through fear of punishment.

The solution, then, lies in an alternative theory of criminal punishment that aspires to more than specific and general deterrence. Absent an extraordinarily broad theory of jurisdiction for extraterritorial crime no theory of punishment can extend deterrence's sphere influence to reach foreign competitors. What extraterritorial criminal enforcement needs, then, is a foundational theory of punishment that looks beyond the potential violators within its jurisdiction and engages with the broader social and legal environment in which the crime occurred. Criminal theory provides three basic possibilities: deterrence, retribution, and rehabilitation/restoration. ${ }^{86}$

The above critique of extraterritorial enforcement will typically first evoke a retributivist response: we punish these corporate criminals to ensure that they

${ }^{86}$ MiETHE \& LU, supra note 21 , at 15. 
get what they deserve, not because of some kind of cost-benefit analysis on social impact. ${ }^{87}$ By this argument U.S. law does not and should not aim to actually reduce crime in overseas countries; we enforce to express our disapproval of the criminal act, and the collateral consequences are quite beside the point.

Applied to extraterritorial white-collar enforcement, the retributivist position is completely coherent. And absent a contrary policy commitment, retribution would provide a sufficient justification for extraterritorial enforcement efforts. But this Article is based on the premise that in certain areas of law - anti-bribery being the best example - our statutes are in fact based on the expectation that our enforcement efforts would reduce crime in the countries in which we do business.

What is needed, then, is a theory of criminal justice that seeks to reduce crime but looks beyond the potential offender's cost-benefit analysis. That theory is restorative justice. Though typically associated with traditional crimes committed by natural persons, Part IV will argue that restorative justice can, and should, apply to extraterritorial corporate crime. Part IV.A will describe the restorative justice approach and show that it is now in practice in federal white-collar environmental enforcement in the form of supplemental sentences. Part IV.B will explain how the U.S. Constitution provides the contours of this sentencing practice: a constitutional tension between the executive and legislative functions ultimately produced a series of guidelines for supplemental sentences that are readily transferable to extraterritorial white-collar enforcement. Part IV.C will then show that supplemental sentences are likewise already authorized, and indeed encouraged, under existing federal sentencing law. Finally, Part IV.D will describe the unexpectedly simple solution to the problem that this Article has taken such pains to describe: the transference of existing domestic white-collar enforcement procedures to extraterritorial enforcement.

\section{A. The Corporate Criminal as Social Healer}

A body of scholarship has long argued for moving away from the traditional adversarial model of legal practice and toward an understanding of the lawyer as a "peacemaker." By this account, the lawyer's aim in practice is to prevent future conflict by understanding and improving social interactions between offender, victim, and community. ${ }^{88}$ Lawyering is thus recast as a "healing profession," taking a "restorative" approach to the practice of law. ${ }^{89}$

${ }^{87}$ Id. at 16; see Philip BeAn, Punishment: A Philosophical AND CRiminological INQUIRY 13 (1981); Joel Feinberg, The Expressive Function of Punishment, in Philosophical Perspectives on Punishment 25, 30 (Gertrude Ezorsky ed., 1972).

${ }^{88}$ Forrest S. Mosten, Lawyer as Peacemaker: Building a Successful Law Practice Without Ever Going to Court, 43 FAM. L.Q. 489, 489 (2009).

${ }^{89}$ Susan Daicoff, Law as a Healing Profession: The "Comprehensive Law Movement,” 6 PEPP. DISP. RESOL. L.J. 1, 1 (2006). 
Suffice it to say that this literature is not typically associated with multinational corporate practice. But might it be? Can multinational corporations, who have committed crimes, heal social wounds? Can corporate defense counsel, and federal prosecutors, be peacemakers? This section posits that the answer is yes. But it is not a mere potentiality. I argue that this is already happening, in federal white-collar criminal enforcement, and that those practices can extend - indeed, should extend - to extraterritorial white-collar crimes.

Restorative justice (RJ) emerged in the 1970s in response to widespread perceptions that the criminal justice system "neither effectively deterred crime nor successfully rehabilitated offenders." 90 RJ differs from deterrence in focusing on more than just the defendant and its cost-benefit analysis. Rather than deterrence's exclusive focus on the defendant, RJ focuses on three distinct "stakeholders" to crime: the victim(s), the offender(s), and the affected communities. ${ }^{91}$ It involves all three stakeholders in the sentencing, and is based on the fundamental principle that criminal behavior not only violates the law, but "also injures victims and the community." 92 Core assumptions of RJ include: the response to crime should repair the harm to the victim as much as possible; offenders should recognize the impact of the harm on the victim and the community; victims should have an opportunity to express their needs and participate in the determining the best way to make reparation; and the community has a responsibility to contribute to this process. ${ }^{93}$ It aims not just to punish and prevent crime, but to actually restore the relationship between the offender, the victim, and the social environment. The victim is restored, the offender recognizes his wrong, and the fear of crime is diminished for the community. ${ }^{94}$

Accordingly, where deterrence is one-dimensional in its focus on the offender, RJ is three-dimensional: in addition to the offender, it focuses on the victim as well as the social environment that gave rise to the offense. RJ has been defined as a form of punishment that is primarily oriented towards doing justice by restoring the harm that has been caused by a crime. ${ }^{95}$ It focuses on repairing or compensating the victim, in order to restore the public's confidence that the crime has been condemned, disapproving of the norm

${ }^{90}$ Carrie Menkel-Meadow, Restorative Justice: What Is It and Does It Work?, 3 ANN. REV. L. \& SOC. SCI. 161, 163 (2007).

${ }^{91}$ BRAITHWAITE, supra note 7, at 11.

92 UNITED NATIONS OFFICE ON DRUGS \& CRIME, supra note 7, at 6.

93 Id. at 8.

${ }^{94}$ Andrew von Hirsch et al., Specifying Aims and Limits for Restorative Justice: A 'Making Amends' Model?, in Restorative Justice And Criminal Justice: Competing OR RECONCILABLE PARADIGMS? 21, 22 (Andrew von Hirsch et al. eds., 2003).

95 See Gordon Bazemore \& Lode Walgrave, Restorative Juvenile Justice: In Search of Fundamentals and an Outline for Systemic Reform, in RESTORATIVE JUVENILE JUSTICE: REPAIRING THE HARM OF YOUTH CRIME 45, 48 (Gordon Bazemore \& Lode Walgrave eds., 1999). 
transgression, and reassurance of the norm and norm enforcement to the public, victims, and offenders. ${ }^{96}$ This focus on the victim might be called the second dimension of punishment.

But RJ is not merely a set of outcomes; so too is it a process by which the victim, offender, and affected community members "participate ... actively in the resolution of matters arising from the crime." 97 This involvement of the community introduces the third dimension. Indeed, another scholar has defined RJ as "a process whereby all the parties with a stake in a particular offence come together to resolve collectively how to deal with the aftermath of the offence and its implications for the future." 98 Through the process, both the victim and the offender come to understand the factors that gave rise to the damaging behavior. 99 "Others who had a role to play in the offence or the circumstances that led to it are also encouraged to assume responsibility for their part...."100 The process "encourages frank discussion of the background of the offence in a spirit of explanation rather than making excuses."101 Ultimately, the sentencing process should be helpful in "identifying underlying causes of crime and developing crime prevention strategies." 102

However, in focusing on the victim and the community, RJ need not call attention away from, or otherwise "go light" on, the offender. Much scholarship has addressed the question of whether punishment of the offender is indeed consistent with restorative goals. Early RJ thought was characterized by a dichotomy. Advocates of RJ argued that in seeking restoration we must eschew retribution and punishment, while advocates of punishment argued punishment must always be the primary aim of the state's response to crime, and that restoration must be a secondary goal that can be pursued only insofar as it does not compromise retribution's core values of justice, proportionality, and fairness. ${ }^{103}$ But others have demonstrated this dichotomy to be false: that retribution remains an important component of RJ, and that full restoration actually requires retribution and punishment. ${ }^{104}$ Indeed, insofar as restoration still aims to give victims and community members reassurance both that justice has been served, and that future harms have been prevented,

96 See Lode Walgrave, Imposing Restoration Instead of Inflicting Pain: Reflections on the Judicial Reaction to Crime, in RESTORATIVE JustiCE AND CRIMINAL JustiCE: COMPETING OR RECONCILABLE PARADIGMS?, supra note 94, at 61, 65.

${ }^{97}$ E.S.C. Res. 2002/12, U.N. Doc. E/2000/INF/2/Add.2, at I.2 (July 24, 2002).

98 BRAITHWAITE, supra note 7, at 11 .

99 UNITED NATIONS OFFICE ON DRUGS \& CRIME, supra note 7, at 9.

$100 \mathrm{Id}$. at 11 .

${ }^{101} \mathrm{Id}$

102 Id. at 10 .

103 Antony Duff, Restoration and Retribution, in RESTORATIVE JUSTICE AND CRIMINAL JUSTICE: COMPETING OR RECONCILABLE PARADIGMS?, supra note 94, at 43, 43.

${ }^{104}$ Id. 
punishment is essential. RJ programs "complement rather than replace the existing criminal justice system."105

But the punishment is different: it is not merely symbolic, nor is it aimed merely at deterrence, whether specific or general. Rather, the offender's restoration is enhanced by his voluntary participation and cooperation in the process. His voluntary agreement to repair or compensate "expresses his understanding of the wrongs committed and harms caused, as well as his willingness to make amends." 106 A restorative outcome is, by definition, an agreement. 107 RJ thus provides the offender "with an opportunity to make meaningful reparation." 108 Punishment is a means, not an end; restoration is the end. 109

As RJ evolved in practice, several core practices emerged. Both the offender(s) and the victim(s) participate directly and personally in a process of speaking about their role in the crime and listening to the other's narrative. Each talks about what occurred, why it occurred, and the harm it caused. The offender acknowledges his conduct and its wrongfulness, and apologizes to the $\operatorname{victim}(\mathrm{s})$. The victim(s) draw into a deeper understanding of the causes, sometimes systemic, of the crime, and can sometimes work toward an attitude of forgiveness (but not forgetfulness) of the act. All persons contribute to a determination of the appropriate restitution. Among the goals of restitution is the reintegration of the wrongdoer into the larger community. Ideally, the wrongdoer and the victim achieve a degree of reconciliation and a shared understanding of appropriate social norms. Both then try to adopt a futureoriented perspective that focuses on the rebuilding of social relationships. ${ }^{110}$ These practices expose deeper truths about state-sanctioned criminality, allow for deeper understandings among the perpetrators and the victims, and can allow a society to "begin anew with transformative understandings of both its past and its future."111

The suggestion that this theory of punishment could apply to any meaningful extent to multinational corporate crime will give rise to three objections. The first is that RJ is designed for traditional crimes involving natural-person offenders and discrete victims, not large-scale institutional crimes. And the premise is to a large extent true: RJ tends to be most widely practiced and discussed in relation to traditional, discrete crimes involving smaller communities and utilizing alternative sentencing procedures such as victim-offender mediation, community and family group conferencing, circle sentencing, and peacemaking circles. ${ }^{112}$

105 UnITED NATIONS OFFICE ON DRUGS \& CRIME, supra note 7, at 13.

106 Walgrave, supra note 96 , at 62.

107 UNITED NATIONS OFFICE ON DRUGS \& CRIME, supra note 7, at 7.

108 Id. at 11 .

109 Walgrave, supra note 96 , at 64.

${ }^{110}$ Menkel-Meadow, supra note 90, at 164.

${ }^{111} \mathrm{Id}$. at 169 .

112 United NATIONS OfFICE ON DRUGS \& CRIME, supra note 7, at 14-15. 
But RJ has since expanded, and arguably its most-widely recognized form today is indeed a large-scale institutional crime with dispersed victims: the Truth and Reconciliation Commission. In the 1990s restorative justice practices moved from individual acts of wrongdoing to systematic wrongdoing by state actors, such as civil wars and illegitimate regimes such as apartheid. ${ }^{113}$ Since then, more than twenty-five developing countries have instituted variations of restorative justice principles to heal from large-scale crimes in which the state participated. If RJ can apply to crimes committed on this scale, by institutional actors against broad communities, it can no less easily apply to corporate crimes.

Skeptics may counter with two additional points, both of which are refuted by the same body of evidence. First, a difference allegedly remains between the state crimes that truth and reconciliation commissions address, and whitecollar crimes. While the former had concededly given rise to RJ approaches, applying RJ to multinational corporate crime may be unworkable, and at any rate is normatively unpalatable. ${ }^{114}$ Second, skeptics will argue that even if RJ for white-collar crime is workable in theory, the enforcement agencies will never embrace such an outlandish and academic proposition. ${ }^{115}$

Neither is true. For twenty-five years, the U.S. Department of Justice has applied alternative sentencing practices to white-collar defendants. In conjunction with the U.S. Environmental Protection Agency, the DOJ has developed a robust and well-defined practice of what is called the "supplemental sentence." The civil-side version of these sentences is perhaps better known, as it has a catchier moniker: the Supplemental Environmental Project, or SEP. But an almost identical practice exists in criminal enforcement, and this practice resounds in RJ themes.

In recent years supplemental projects have increased in popularity and visibility. The DOJ has provided several reasons why this is so, all of which readily apply to extraterritorial white-collar crime. First, prosecutors "want to rectify the wrongs" caused by violations, and feel that more conventional

\footnotetext{
113 Menkel-Meadow, supra note 90, at 169.

${ }^{114}$ Some scholars have discussed, however tentatively, the possibility of applying RJ to white-collar crime. See BRAITHWAITE, supra note 7, at 62-66. One of the founders of the restorative justice movement, John Braithwaite of Australia National University, has argued for its applicability to corporate crime. Id. He finds that when state regulators participate in negotiations with corporate managers or industry leaders, the resulting enforcement actions are more flexible and realistic, and the punishment is generally much more effective than traditional deterrence measures in promoting corporate compliance. Id.; see Marianne Löschnig-Gspandl, Corporations, Crime and Restorative Justice, in Restorative Justice in ConteXt: InTERnAtional Practice AND Directions 145, 145 (Elmar G.M. Weitekamp \& Hans-Jürgen Kerner eds., 2003).

115 The U.S. Department of Justice has, in other contexts, explicitly embraced RJ in the context of other areas of crime. See U.S. DEP'T OF Justice, IDENTIFYING Culturally RESPONSIVE ViCTIM-CENTERED RESTORATIVE Justice STRATEGIES (2012), available at http://ojp.gov/ovc/grants/pdftxt/FY2012_Identifying_Culturally_Responsive_Victim.pdf, archived at http://perma.cc/GR25-24CB.
} 
criminal sentences fail to do so. Second, corporate defendants frequently wish to perform community service and actually prefer it to simply paying a fine, even where the service may prove more expensive. Third, judges often feel that they are "doing more good for the community" by using the settlement funds for community service instead of depositing those funds in the U.S. treasury. ${ }^{116}$

Note how naturally these three policy goals would apply to many forms of white-collar crime; they are in no way unique to environmental violations. Indeed, they are especially applicable to extraterritorial bribery, where multiple stakeholders have for years criticized modern enforcement for its failure to compensate the victims and otherwise improve the conditions in the communities where the bribes occurred.117 As is always the case with extraterritorial enforcement, the crime occurred overseas, but the fine is deposited in the U.S. treasury. The real victims - those impacted directly by the crime-obviously receive scant benefit from the deposit. ${ }^{118}$

Notice also the obvious RJ themes in this analysis. The prosecutors wish to remedy the harm and not merely punish the defendant. Corporate defendants often express a preference for community service; though they may well be motivated by concerns for reputation and, by extension, long-term profits, they nonetheless are seeking to restore their relationship to the community to its pre-crime state. And the judges also see greater community benefits in the supplemental sentences; more to the point, they believe that these benefits are a legitimate and appropriate aim of criminal sentencing.

Several recent examples of supplemental sentences illustrate this. In 2009, a gas company paid a total of $\$ 18$ million for illegally storing mercury. The sentence included a $\$ 6$ million criminal fine and $\$ 12$ million in payments to various local community initiatives to support environmental remediation and

${ }^{116}$ Kris Dighe, Organizational Community Service in Environmental Crimes Cases, U.S. ATT'Y BULL., July 2012, at 100, 100, available at http://www.justice.gov /usao/eousa/foia_reading_room/usab6004.pdf, archived at http://perma.cc/TN3Y-3L9G.

${ }^{117}$ See Letter from Alexander W. Sierck to Robert S. Khuzami, Dir., Enforcement Div., U.S. Sec. \& Exch. Comm'n (Apr. 25, 2012), available at http://www.fcpablog.com /blog/2012/3/16/african-ngo-asks-for-distribution-of-fcpa-recoveries.html, archived at http://perma.cc/2RVR-E7XK; see also Matthew C. Turk, A Political Economy Approach to Reforming the Foreign Corrupt Practices Act, 33 Nw. J. INT'L L. \& Bus. 325, 336-40 (2013).

118 Moreover, FCPA enforcement has, perhaps unwittingly, supplied one high-profile example of a quasi-restorative approach to criminal enforcement. In settling the case of James Giffen, the United States arranged with officials in Kazakhstan and Switzerland to release the $\$ 80$ million in alleged bribes from their Swiss accounts and establish a trust fund to be managed by a Kazakhstani NGO. David Glovin, Oil Dealer Giffen Avoids Prison in Onetime Bribe Case, Bloomberg L., Nov. 19, 2010, at 3. This fund was to be used to pay for programs for poor children and improve transparency in the Kazakh oil industry. $I d$. 
education projects and children's health initiatives. ${ }^{119}$ In 2010, a ship management firm paid a total of $\$ 10$ million to settle criminal violations of the Oil Pollution Act for causing and covering up an oil spill after one of its ships hit the San Francisco Bay Bridge. Pursuant to the plea agreement, \$2 million of the total $\$ 10$ million will fund marine environmental projects in San Francisco Bay. ${ }^{120}$ In 2012, a producer of pesticides agreed to pay a criminal fine and perform community service to settle eleven criminal violations of the Federal Insecticide, Fungicide and Rodenticide Act in relation to applying insecticides to its wild bird food products. In addition to the $\$ 4$ million criminal fine, the defendant contributed $\$ 500,000$ to various organizations that protect bird habitat in the immediate vicinity of the violations to fund conservation, research, and education. ${ }^{121}$

But 2013 proved to be the true zenith of community service sentences for environmental white-collar criminals, producing two especially high-profile cases. The first was Wal-Mart, which plead guilty to six criminal counts of violating the Clean Water Act for illegally handling and disposing of hazardous materials at its retail stores across the United States. Wal-Mart was sentenced to pay a $\$ 40$ million criminal fine, and an additional \$20 million that will fund various community service projects, including opening a $\$ 6$ million Retail Compliance Assistance Center that will help retail stores across the nation learn how to properly handle hazardous waste. ${ }^{122}$

However, the largest and most significant sentence came in the BP Gulf of Mexico settlement. Not only was it the largest community service sentence in environmental enforcement history, but BP also paid the largest criminal fine of any kind in all of U.S. history: $\$ 4$ billion, over three times larger than the next-largest criminal resolution ever paid. ${ }^{123}$ The resolution is structured so

${ }^{119}$ Press Release, U.S. Dep't of Justice, Southern Union Company Is Penalized \$18 Million for Illegally Storing Mercury at a Rhode Island Site 1 (Oct. 2, 2009), available at http://www.justice.gov/opa/pr/2009/October/09-enrd-1070.html, archived at http://perma.cc/XT9N-AREE.

${ }^{120}$ Press Release, U.S. Dep't of Justice, Shipping Firm Sentenced to Pay \$10 Million for Causing Cosco Busan Oil Spill and Coverup 1 (Feb. 19, 2010), available at http://www.justice.gov/opa/pr/2010/February/10-enrd-168.html, archived at http://perma.cc/435U-VDXU.

${ }^{121}$ Press Release, U.S. Dep't of Justice, Scotts Miracle-Gro Will Pay \$12.5 Million in Criminal Fines and Civil Penalties for Violations of Criminal Pesticide Laws 2 (Sept. 7, 2012), available at http://www.justice.gov/opa/pr/2012/September/12-enrd-1088.html, archived at http://perma.cc/Y7KT-88AZ. Scotts also paid civil penalties and performed additional service projects related to its civil liability. See id.

122 Press Release, U.S. Dep't of Justice, Wal-Mart Pleads Guilty to Federal Environmental Crimes, Admits Civil Violations and Will Pay More than \$81 Million 2 (May 28, 2013), available at http://www.justice.gov/opa/pr/2013/May/13-enrd-611.html, archived at http://perma.cc/NE36-DNXA. Wal-Mart also pled guilty to violating the Federal Insecticide, Fungicide and Rodenticide Act by failing to properly handle pesticides. Id. at 1 .

123 The previous largest criminal resolution was $\$ 1.3$ billion, paid by Pfizer in 2009 for off-label pharmaceutical marketing. See Reasons for Accepting Plea Agreement at 11 n.15, 
that more than half of this recovery will fund projects to compensate those communities and ecosystems most directly harmed by the spill. As the government's own press release explained:

[A]pproximately $\$ 2.4$ billion of the $\$ 4.0$ billion criminal recovery is dedicated to acquiring, restoring, preserving and conserving - in consultation with appropriate state and other resource managers - the marine and coastal environments, ecosystems and bird and wildlife habitat in the Gulf of Mexico and bordering states harmed by the Deepwater Horizon oil spill. This portion of the criminal recovery will also be directed to significant barrier island restoration and/or river diversion off the coast of Louisiana to further benefit and improve coastal wetlands affected by the oil spill. An additional $\$ 350$ million will be used to fund improved oil spill prevention and response efforts in the Gulf through research, development, education and training. ${ }^{124}$

The money is going primarily to the National Fish and Wildlife Foundation, an independent, non-profit conservation group. ${ }^{125}$ An additional \$350 million will go to the National Academy of Sciences for oil spill prevention, education, research, and training. ${ }^{126}$ These organizations are required under the court order to spend the monies on projects specifically related to the oil spill to the extent possible. ${ }^{127}$ These penalties are in addition to the required monitors, audits, training programs, and other internal reforms.

Notice again the RJ themes in these environmental examples. The sentences directly repair the harm that resulted from the violation, thus restoring the victims. Through research and education, the broader causes of the harm are studied and addressed; the sentences work toward prevention not merely by imposing a fine that would deter other prospective violators, but by changing the environment that gave rise to the violation. To identify the most effective measures, the defendant consults members of the local community with particular expertise.

Commentators have consistently noted the RJ themes of these sentences, and the ways in which they move substantially beyond deterrence-based approaches to more effectively remedy and prevent harms. The ABA

United States v. BP Exploration \& Prod., Inc., No. 12-292 (E.D. La. Jan. 20. 2013), available at http://www.justice.gov/criminal/vns/docs/2013/01/2013-01-30-bp-explorationreasons-for-accepting-plea-agreement.pdf, archived at http://perma.cc/T2L7-SA8X.

${ }^{124}$ See Press Release, U.S. Dep't of Justice, BP Exploration and Production Inc. Agrees to Plead Guilty to Felony Manslaughter, Environmental Crimes and Obstruction of Congress Surrounding Deepwater Horizon Incident (Nov. 15, 2012), available at http://www.justice.gov/opa/pr/2012/November/12-ag-1369.html, archived at http://perma.cc/C4T4-B6MM.

125 Guilty Plea Agreement Exhibit B at 16, United States v. BP Exploration \& Prod., Inc., No. 12-292 (E.D. La. Nov. 2012), available at http://www.justice.gov/iso/opa /resources/43320121115143613990027.pdf, archived at http://perma.cc/TQ8G-73SA.

126 Id.

127 See Order at 16-19, United States v. BP Exploration \& Prod., Inc., No. 12-292 (E.D. La. Jan. 29, 2013), available at http://www.justice.gov/criminal/vns/docs/2013 /01/2013-01-29-bp-exploration-order.pdf, archived at http://perma.cc/D5H9-EBCB. 
explained that these sentences are designed to "improve or repair relationships among all stakeholders (i.e., impacted communities, facilities, and government, at all levels) following the environmental violation." 128 More to the point, Michael L. Rustad, Thomas H. Koenig, and Erica R. Ferreira provide an extensive case-study analysis of the RJ themes of supplemental sentences, observing that they "creatively combine[] both deterrence-based punishment through ... penalties and restorative justice principles in the form of mitigation projects ...." 129 Notably, those authors suggest that "[o]ther regulatory agencies should consider adopting restorative justice insights in designing remedies" for other forms of white-collar crime. ${ }^{130}$

This Article will shortly provide an outline for doing that very thing. But further context is necessary to understanding how and why these sentences are authorized under existing federal law. The following section explains how constitutional pressures have shaped the formation of the guidelines that would now apply to any such sentences.

\section{B. Authorization in the U.S. Constitution}

Congress and various federal agencies have argued for years about whether the U.S. Constitution permits an enforcement agency to unilaterally divert de facto criminal penalties to community service projects. Supplemental sentences walk a fine line between the Executive's enforcement authority ${ }^{131}$

${ }^{128}$ Nicholas Targ \& David Jung, Preface to Pub. LAW Research Inst., Supplemental Environmental Projects: A Fifty State Survey with Model PRACTICES 3 (2007), available at http://gov.uchastings.edu/public-law/docs/plri/ABA HastingsSEPreport.pdf, archived at http://perma.cc/HT5H-X9NL; see Dika Kuoh, Leveraging Enforcement to Enhance Community: The Use of Supplemental Environmental Projects to Promote Environmental Justice 3 (May 2013) (unpublished Masters thesis, Duke University), available at http://dukespace.lib.duke.edu/dspace/handle/10161/6849, archived at http://perma.cc/5H9Y-MF95.

${ }^{129}$ Michael L. Rustad et al., Restorative Justice to Supplement Deterrence-Based Punishment: An Empirical Study and Theoretical Reconceptualization of the EPA's Power Plant Enforcement Initiative, 2000-2011, 65 OKLA. L. REV. 427, 428 (2013).

130 Id.

131 See U.S. CONST. art. I, § 9, cl. 7. In Federalist 58, Madison wrote that

"they [(Congress)], in a word, hold the purse ... This power over the purse may, in fact, be regarded as the most complete and effectual weapon with which any constitution can arm the immediate representatives of the people, for obtaining a redress of every grievance, and for carrying into effect every just and salutary measure."

The Federalist No. 58, at 284-85 (James Madison) (Terrence Ball ed., 2003). So too did the Supreme Court hold that "no money can be paid out of the Treasury unless it has been appropriated by an act of Congress." Cincinnati Soap Co. v. United States, 301 U.S. 308, 321 (1937) (citing Reeside v. Walker, 52 U.S. 272, 291 (1851)); see Robert C. Byrd, The Control of the Purse and the Line Item Veto Act, 35 HARV. J. ON LEGIS. 297, 297 (1998); Richard D. Rosen, Funding "Non-Traditional” Military Operations: The Alluring Myth of 
and the congressional power of the purse. ${ }^{132}$ Seeking to protect its power from executive encroachment, Congress enacted the Miscellaneous Receipts Act (MRA), ${ }^{133}$ requiring that any money received "for the Government" from any source be deposited into the U.S. treasury. ${ }^{134}$ The MRA is "intended to preserve Congressional prerogatives to appropriate funds as provided for in the U.S. Constitution." 135 Sentencing policy must therefore allow the Executive Branch to exercise its settlement authority without encroaching upon Congress's appropriation power.

In the 1980s and early 1990s, various enforcement agencies-including the Commodity Futures Trading Commission, ${ }^{136}$ the Nuclear Regulatory

a Presidential Power of the Purse, 155 MIL. L. REV. 1, 1 (1998); Kate Stith, Congress' Power of the Purse, 97 YALE L.J. 1343, 1349 (1988); see also Charles Tiefer, Controlling Federal Agencies by Claims on Their Appropriations? The Takings Bill and the Power of the Purse, 13 Yale J. ON REG. 501, 502 (1996).

132 The Judiciary Act of 1789 vests plenary authority over the legal affairs of the United States in the Attorney General, and Congress created the Attorney General's statutory authority to conduct litigation on behalf of the United States when establishing the Department of Justice in 1870. Todd David Peterson, Protecting the Appropriations Power: Why Congress Should Care About Settlements at the Department of Justice, 2009 BYU L. REV. 327, 342-43.

${ }^{133}$ Miscellaneous Receipts Act, Pub. L. No. 97-258, 96 Stat. 948 (1982) (codified as amended at 31 U.S.C. $\S 3302$ (2012)).

134 U.S. DeP'T of Justice, Sentencing Guidance in EnVironmental Prosecutions, InCluding the Use of Supplemental Sentencing Measures, DeVeloped By the U.S. DEPARTMENT OF JUSTICE, ENVIRONMENT AND NATURAL RESOURCES DIVISION, ENVIRONMENTAL CRIMES SECTION IN CONSULTATION WITH THE ENVIRONMENTAL CRIMES Policy COMmittee B-11 (2000) [hereinafter ENVIRONMENTAL SENTENCING GuIDANCE].

135 Memorandum from Walker B. Smith, Dir., Office of Regulatory Enforcement, U.S. Envtl. Prot. Agency, to Reg'l Counsel, Reg'l Enforcement Div. Dirs., \& Reg'l Media Div. Dirs. 2 (Oct. 31, 2002) [hereinafter Nexus Memo], available at http://www2.epa.gov /sites/production/files/documents/sepnexus-mem.pdf, archived at http://perma.cc/6D8MZ2VR.

${ }^{136}$ In 1983, the Commodity Futures Trading Commission (CFTC) sought an opinion from the Government Accounting Office concerning its proposed policy of accepting a defendant's promise to make a donation to an educational institution as all or part of a settlement agreement. See Commodity Futures Trading Comm'n, B-210210, 1983 WL 197623 (Comp. Gen. Sept. 14, 1983). The CFTC specifically wanted to know if achieving its educational goals through the proposed plan would violate the MRA. See id. In striking down the proposal, the Comptroller General held that the donations would effectively be penalties, which are subject to deposit into the Treasury under the MRA, and that the CFTC's means of enforcement are "specifically defined" by Congress and that settlement authority should be "limited to statutorily authorized prosecutorial objectives: correction or termination of a condition or practice, punishment, and deterrence." Id. The Comptroller General further took issue with the fact that a charged party would donate funds to "an educational institution that has no relationship to the violation and that has suffered no injury from the violation." Id. In concluding that the CFTC must collect those penalties and deposit them into the Treasury in compliance with the MRA, the Comptroller General added, "[t]he Commission may not circumvent the receipt of a penalty to accomplish a separate objective." Id. 
Commission, ${ }^{137}$ and ultimately the Environmental Protection Agency ${ }^{138}$ claimed the authority to use a portion of civil settlements to fund community service projects, with repeated pushback from the Comptroller General. Then in 1993, the Comptroller General finally acknowledged that the U.S. Constitution and the MRA may indeed authorize the funding of such projects under certain, carefully prescribed conditions. ${ }^{139}$ It explained that the Government's

discretionary authority to 'compromise, or remit, with or without conditions,' civil penalties... empowers it to adjust penalties to reflect the special circumstances of the violation or concessions exacted from the violator, but does not extend to remedies unrelated to the correction of the violation in question. ${ }^{140}$

This "adjustment" of penalties to reflect the violator's "concessions"provided those concessions are "related" to the violation-marked the birth of the supplemental sentence. The Comptroller General essentially conceded that such projects could actually fall within the Executive's legitimate enforcement

${ }^{137}$ U.S. Nuclear Regulatory Comm'n, 70 Comp. Gen. 17 (1990) (regarding the Nuclear Regulatory Commission's authority to mitigate civil penalties in exchange for contributions to nuclear safety research projects at universities and other nonprofit institutions). Under the Atomic Energy Act, the NRC is authorized to impose civil monetary penalties for violations of licensing requirements and to compromise, mitigate, or remit those penalties as well. See 42 U.S.C. § 2282(a) (2012). The Comptroller General applied a similar line of reasoning as in Commodity Futures Trading Comm'n, B-210210, 1983 WL 197623 (Comp. Gen. Sept. 14, 1983), in determining that the proposed alternative was not within the Commission's congressionally delegated powers. U.S. Nuclear Regulatory Comm'n, 70 Comp. Gen. 17 (1990). The Commission's discretion to impose monetary penalties, "like CFTC's prosecutorial discretion, does not empower the NRC to impose punishments unrelated to prosecutorial objectives." Id. The Comptroller General elaborated, “[u]nder NRC's proposal, a violator would contribute funds to an institution that, in all likelihood, has no relationship to the violations and has suffered no injury from the violation." Id. The Comptroller General again maintained that allowing an agency to impose punishments unrelated to prosecutorial objectives would allow that agency to circumvent the MRA. Id. This opinion also added that the proposal would violate the general rule against augmentation of appropriation. $I d$.

${ }^{138}$ U.S. Nuclear Regulatory Comm'n, B-247155, 1992 WL 726317 (Comp. Gen. July $7,1992)$. The EPA contended that its power to compromise or remit civil penalties with or without conditions under section 205 of the Clean Air Act provided a legal basis for its practice of funding public awareness projects with civil penalties. The opinion rejected the EPA's proposal, finding that using penalty money to fund such projects would violate the MRA in all the ways it had previously explained: where the proposed project was not designed to remedy and prevent the specific harms caused by the violation, it would violate congressional appropriations power generally and the MRA specifically. Id.

${ }^{139}$ U.S. Envtl. Prot. Agency, B-247155.2, 1993 WL 798227 (Comp. Gen. Mar. 1, 1993).

${ }^{140} I d$. (internal quotation marks omitted). 
authority and not run afoul of either Congress's Article I power of the purse or the MRA. ${ }^{141}$

Within two years, the EPA would translate the Comptroller General's guidance into an Interim Revised Supplemental Environmental Projects Policy. ${ }^{142}$ This publication also introduced the catchy civil-side moniker of the Supplemental Environmental Project, or "SEP." The EPA clarified these civil enforcement guidelines in 1998, when it promulgated its Final EPA Supplemental Environmental Projects Policy. ${ }^{143}$ The DOJ then translated these civil enforcement guidelines into criminal sentencing guidance in a 2000 DOJ memo. ${ }^{144}$ The 2000 guidelines would be rearticulated in a 2012 United States Attorneys' Bulletin. ${ }^{145}$ And as far back as the mid-1990s, the EPA and DOJ were administering supplemental sentences with some frequency. ${ }^{146}$

The DOJ has explained that in addition to the goals of deterrence and corporate compliance, supplemental sentencing measures can "more fully remedy the harm to the environment and the community caused by the violation ...."147 It articulates several guidelines that, if followed, can keep the sentence within executive authority. Notice again how readily they transfer to anti-bribery law specifically and extraterritorial white-collar crime generally.

The first and most fundamental requirement, arising directly from the Government Accountability Office opinions, is the nexus requirement. "Nexus is the relationship between the violation and the proposed project[,]"148 and the purpose of the nexus is to ensure that any harm or threatened harm to victims or the environment is actually addressed. ${ }^{149}$ It further ensures that supplemental projects "do not run afoul of any Constitutional and statutory requirements" by circumventing congressional authority to allocate the monies of the U.S. treasury. ${ }^{150}$ The enforcement agencies have developed three circumstances in which the nexus may be satisfied: first, where the project is "designed to reduce the likelihood that similar violations will occur in the future"; second, where the project "reduces the adverse impact" of the violation; or third, where the project "reduces the overall risk" to the

${ }^{141}$ Id.

${ }^{142}$ Final EPA Supplemental Environmental Projects Policy Issued, 63 Fed. Reg. 24,796 (May 5, 1998).

143 Id.

144 See ENVIRONMENTAL SENTENCING GuIDANCE, supra note 134, at A-1.

145 Dighe, supra note 116 , at 104.

${ }^{146}$ For examples of early supplemental sentences, see ENVIRONMENTAL SENTENCING GUIDANCE, supra note 134 , at B-1 to B-20.

${ }^{147} \mathrm{Id}$. at A-1. The measures can also "encourage more efficient environmental technologies and corporate management practices, leverage greater environmental and public health improvements, and advance important priorities like pollution prevention." Id.

\footnotetext{
148 Id. at B-15 n.49.

${ }^{149} \mathrm{Id}$.

${ }^{150}$ Nexus Memo, supra note 135.
} 
community affected by the violation. ${ }^{151}$ Notably, EPA Guidelines specifically mention that a nexus can exist even where the project "will involve activities outside of the United States."152

Secondly, and relatedly, the enforcement agencies cannot approve any project that supplements, or appears to supplement, either their own appropriations or the appropriations of another federal agency. ${ }^{153}$ This "anti augmentation principle" holds that an improper augmentation of appropriations occurs in any of three circumstances: (1) where a supplemental project helps to carry out a project for which the enforcement agencies or other agencies already have funding; (2) where the federal government is required by law to carry out the project; or (3) where the project is already in existence and already receives federal funding. ${ }^{154}$ For this reason, the supplemental project must specifically address the harm that resulted from the violation, and/or take new measures to prevent similar future harms. Ultimately, if there is a close relationship between the violation and the supplemental project, the enforcement agencies have the discretion to consider the cost of the project when calculating the overall settlement; "if there is no nexus, then the [agencies do] not have that discretion."155

Third, the defendant must retain full responsibility for completion of the project; it may not merely give a cash donation to an organization. A cash donation, absent responsibility for completion of a discrete project, would violate the MRA. ${ }^{156}$ Any trust fund created by a supplemental sentence must be managed by a non-federal entity - whether a charity, educational institution, public interest group, or other organization - that is chosen without favoritism or the appearance of favoritism. ${ }^{157}$ The trust fund should be managed by neutral third parties, or the money may be deposited in an escrow account and distributed at regular intervals until the project is completed. Federal officials may provide technical oversight to ensure that the project is

${ }^{151}$ Final EPA Supplemental Environmental Projects Policy Issued, 63 Fed. Reg. 24,796, 24,798 (May 5, 1998).

152 Id

${ }^{153}$ Nexus Memo, supra note 135, at 23; see also ENVIRONMENTAL SENTENCING GUIDANCE, supra note 134, at B-11.

154 Nexus Memo, supra note 135, at 2-3; see also Motor Coach Indus., Inc. v. Dole, 725 F.2d 958, 964-65 (4th Cir. 1984); U.S. Gen. ACCOUNTING OfFice, 2 PRINCIPLES OF FEDERAL APPROPRIATIONS LAW 6-162 to 6-163 (3d ed. 2004).

155 Nexus Memo, supra note 135 , at 2.

${ }^{156}$ Memorandum from John Peter Suarez, Assistant Adm'r, EPA Office of Enforcement \& Compliance Assurance, to Regional Counsels et al. ๆ II.A. (Dec. 15, 2003), available at http://www2.epa.gov/sites/production/files/documents/seps-thirdparties.pdf, archived at http://perma.cc/GYN2-XW3F. This prohibition on cash donations was first articulated by the Office of Legal Counsel opinion concerning a Department of Interior proposal. Steuart Transp. Co., 4B Op. O.L.C. 684, 684 (1980).

157 See ENVIRONMENTAL SENTENCING GUIDANCE, supra note 134, at B-18 to B-19. 
consistent with the sentence but may not actually manage the project or its funding. ${ }^{158}$

The memos enumerate various permitted sentencing objectives: remediation and restoration (taking steps to restore and enhance the environment near the site of the violation); prevention (beyond what is already required by federal environmental law, with the aim of developing innovative new processes); restitution payments to local agencies for their remediation costs; setting up trust funds for the long-term monitoring, restoration, and preservation of the resources impacted by the violation; environmental education (in the form of formal educational programs, regulatory training, and speeches to trade groups); and public apologies (in newspapers and other public media). ${ }^{159}$ Projects that have violated one or more of these guidelines include: general educational or public environmental awareness projects, e.g., conducting tours of an environmental facility or promoting recycling; contributions to research at a college or university; conducting a project of benefit to the harmed community, but unrelated to environmental protection, e.g., making a charitable organization or donating playground equipment; and studies or assessments that do not address the problems they identify.

Note that these guidelines are in no way specific to environmental violations. The constitutional context bears this out; so too do the federal sentencing guidelines themselves. The next section describes how the guidelines now authorize supplemental sentences, and in a way that is fully transferable to other areas of enforcement.

\section{Authorization in the Sentencing Guidelines}

The DOJ could immediately adopt the supplemental sentence in extraterritorial white-collar enforcement. It now lies within the agency's prosecutorial discretion because it is authorized under existing federal law. But

${ }^{158}$ Id. Additionally, the defendant may not obtain tax relief for the value of the supplemental sentence if the same funds were used to pay a fine. $I d$. The principle difference between civil and criminal supplemental environmental sentences concerns the relationship between the cost of the supplemental project and the monetary fine. On the civil side, the EPA has worked a complex and highly specific five-step procedure for determining the settlement amount without a supplemental project, the cost of the project, and the extent of penalty mitigation. See id. Generally speaking, the mitigation should not exceed $80 \%$ of the project's cost. See id. On the criminal side, no such procedure exists. See id. Though the sentencing guidelines provide these steps for other types of crimes, and provide the guidance for environmental crimes on remediation, community service, and probation, the sentencing guidelines expressly do not apply to the calculation of the fine for environmental violations. See Final EPA Supplemental Environmental Projects Policy Issued, 63 Fed. Reg. 24,796, 24,797 (May 5, 1998). Accordingly, though contemporary criminal sentencing in environmental law will frequently involve a combination of supplemental sentences and monetary fines, the extent to which the fine is discounted for the cost of the project is apparently entirely within the prosecutor's discretion. Id.

159 See ENVIRONMENTAL SENTENCING GUIDANCE, supra note 134, at A-6 to A-7. 
the statutory authority for the supplemental sentence does not derive from the environmental statutes or from some kind of specialized amendment to federal sentencing law. Rather, it derives from the standard sentencing sources: the Sentencing Reform Act and the U.S. Sentencing Guidelines.

This subsection will first describe how the guidelines authorize these supplemental sentences. It shows that RJ is actually embedded in the very structure of the guidelines, though in nascent form. It then describes how the supplemental sentence could be adapted to extraterritorial white-collar crime without any new legal authorization.

Chapter 8 of the Sentencing Guidelines Manual provides a distinct set of procedures for the sentencing of organizational defendants. The prosecutor (in a case settled out of court, as anti-bribery cases virtually always are) ${ }^{160}$ first determines the offense level based in part on the value of the benefit received and, consulting a chart in the Guidelines, calculates the base fine. ${ }^{161}$ She then determines a culpability score, which takes into account the size of the organization, the level of personnel involved in the crime, and the extent of the organization's cooperation and acceptance of responsibility. ${ }^{162}$ This culpability score produces two "multipliers," a maximum and a minimum. ${ }^{163}$ The base fine, multiplied by each of the multipliers, then produces a fine range. ${ }^{164}$

But the Guidelines then permit the prosecutor to set an ultimate fine that is below the sentencing range; this is known as a "downward departure," and is permitted for either of two reasons. The first is assistance to the enforcement authorities in the investigation or prosecution of another person, whether an organization or an individual (not affiliated with the defendant). ${ }^{165}$ The second reason, which is particularly germane to the present inquiry, is remedial costs arising from the offense. 166

Two examples can illustrate how the DOJ specifically applies these provisions to extraterritorial white-collar enforcement, again using anti-bribery law as an example. Bizjet, a U.S.-based company that provides aircraft maintenance services to customers around the world, admitted to bribing government officials in Mexico and Panama to win and retain business. ${ }^{167}$ The DOJ calculated the offense level, considering the base offense and the value of

160 See RESOURCE GUIDE, supra note 85, at 74-77 (explaining the government's various methods of settling cases without going to trial).

161 U.S. SENTENCING COMM’N, supra note 8, §§ 8C2.3-2.4.

162 Id. $\$ 8 \mathrm{C} 2.5$.

163 Id. $\S 8 \mathrm{C} 2.6$.

164 Id. \& 8C2.7.

165 Id. $\S 8 \mathrm{C} 4.1$.

${ }^{166}$ Id. $\$ 8 C 4.9$.

${ }^{167}$ Deferred Prosecution Agreement at 1-2, United States v. Bizjet Int'l Sales \& Support, Inc., No. 12-CR-61-CVE (N.D. Okla. Mar. 14, 2012), available at http://www.justice.gov/criminal/fraud/fcpa/cases/bizjet/2012-03-14-bizjet-deferredprosecution-agreement.pdf, archived at http://perma.cc/W5YZ-2V58. 
the benefit, producing a base fine of $\$ 28.5$ million. ${ }^{168}$ The culpability score was then determined based on a base score, the size of the organization, and its voluntary disclosure and cooperation. ${ }^{169}$ The culpability score then produced two multipliers, one high and one low. ${ }^{170}$ The base fine, multiplied by the culpability multipliers, produced a sentence range of $\$ 17.1$ million to $\$ 34.2$ million. ${ }^{171}$ However, the ultimate fine was $\$ 11.8$ million, a $30 \%$ reduction off the bottom of the range. ${ }^{172}$ This reduction was appropriate given, inter alia, Bizjet's "extensive" remediation. ${ }^{173}$ The remediation included implementation of a corporate compliance program, a review of its internal controls, and periodic reports to the DOJ. ${ }^{174}$

Biomet, a U.S.-based company that manufactured and sold orthopedic devices, used its subsidiaries in Argentina, Brazil, China, and Sweden to bribe doctors. Because these doctors were employees of state-owned hospitals, the DOJ treated the doctors as "foreign officials." 175 Per the Guidelines, the DOJ calculated the base offense, considering the base offense level, the number of bribes, the value of the benefit, and Bizjet's "substantial assistance in the prosecution of others," rendering a base fine of $\$ 13.5$ million. It then calculated the culpability score based on a base score, the size of the organization, and Biomet's full cooperation and acceptance of responsibility, again producing two multipliers. The base fine multiplied by the culpability multipliers rendered a fine range of $\$ 21.6$ million to $\$ 43.2$ million. However, as with Biomet, the ultimate sentence was $\$ 17.28$ million, a $20 \%$ reduction of the bottom of the range. This reduction was "appropriate" due in large part to Bizjet's "extraordinary remediation." 176 That remediation included the implementation of a corporate compliance program, the engagement of an independent corporate compliance monitor, and periodic compliance reporting to the DOJ.

These anti-bribery examples show that the DOJ already grants downward departures from the sentencing range for remediation. However, they also show that the allowed remediation has historically been limited to compliance programs, monitors, and reporting. Nevertheless, the Guidelines also allow remediation to include programs funded by the defendant that address the harms that the violation caused. The Guidelines describe these non-monetary penalties (the compliance programs, monitors, reporting requirements, etc.) as "conditions of probation." 177 They permit these conditions of probation in a

168 Id. at 5.

${ }^{169} \mathrm{Id}$.

170 Id

${ }^{171}$ See id.

172 Id.

173 Deferred Prosecution Agreement, supra note 167, at 3-7.

${ }^{174}$ Id. 7-8.

175 See RESOURCE GUIDE, supra note 85, at 19-21.

176 Deferred Prosecution Agreement, supra note 175, at 5.

${ }^{177}$ U.S. SENTENCING COMM'N, supra note 8, ch. 8, pt. D, introductory cmt. 
number of circumstances, two of which are particularly relevant here: where it is "necessary to ensure that changes are made within the organization to reduce the likelihood of future criminal conduct,"178 and to "ensure completion of community service." 179 The remediation that the DOJ already requires - compliance programs, monitors, etc.-falls into the first category: it is necessary to ensure changes within the organization.

The supplemental sentence falls within the second category of probation: community service. Probationary sentences directed to community service derive their authority from the Sentencing Reform Act of 1984, which restructured federal sentencing and established the U.S. Sentencing Commission. ${ }^{180}$ That statute authorizes the court, as a discretionary condition of probation, to order the defendant to "work in community service." 181 The legislative history explains that community service may be "useful" where the victims "cannot be readily identified." 182 This is of course frequently true in environmental law and virtually always true in anti-bribery law: the victims can be a very broad group of individuals. Like the Sentencing Reform Act, the Guidelines provide that where the victims are not identifiable an "order of probation requiring community service" is appropriate. ${ }^{183}$ This community service should be designed "to reduce or eliminate the harm threatened, or to repair the harm caused by the offense, when that harm or threatened harm would not otherwise be remedied." 184 Community service then can, or must, both remedy past harm and prevent future harm. ${ }^{185}$

The supplemental sentence would thus easily fit into existing FCPA sentencing procedures. Following standard procedure, the DOJ would

${ }^{178}$ Id. $\S 8 \mathrm{D} 1.1(\mathrm{a})(6)$.

${ }^{179}$ Id. $\S 8 \mathrm{D} 1.1(\mathrm{a})(1)$.

${ }^{180}$ Sentencing Reform Act of 1984, Pub. L. No. 98-473, 98 Stat. 1987 (codified as amended in scattered sections of 15 and 18 U.S.C.).

18118 U.S.C. $\$ 3563($ b)(12) (2012).

182 ENVIRONMENTAL SENTENCING GUIDANCE, supra note 134, at B-1.

183 The very first policy statement of the "Sentencing of Organizations" chapter of the Guidelines provides that "the court must, whenever practicable, order the organization to remedy any harm caused by the offense." U.S. SENTENCING COMM'N, supra note 8, ch. 8, introductory $\mathrm{cmt}$. That is, the first principle of federal organizational sentencing is not to deter future harm; it is to remedy past harm. Accordingly, the first substantive section of the organizational chapter is indeed entitled "Remedying Harm from Criminal Conduct, and Effective Compliance and Ethics Program." Id. §8B. Notably, the DOJ reads the Guidelines to "support[] the concept that supplemental sentences are important and appropriate." ENVIRONMENTAL SENTENCING GUIDANCE, supra note 134, at B-5.

${ }^{184}$ U.S. SENTENCING COMM’N, supra note $8, \S 8$ B1, introductory cmt.

185 Moreover, the community service is required to "provide[] a means for preventive or corrective action directly related to the offense and therefore serve[s] one of the purposes of sentencing set forth in 18 U.S.C. $\S 3553(\mathrm{a})$." Id. $\S 8 \mathrm{~B} 1.3$, cmt. And those purposes extend well beyond deterrence: in addition to providing "adequate deterrence," the statute provides that criminal sentencing should also, inter alia, protect the public from further violations, promote respect for the law, and provide the defendant with educational training or other "correctional treatment." 18 U.S.C. § 3553(a)(2)(D) (2012). 
calculate the base fine and the culpability multipliers, and set a fine range. It would then consider whether to grant a downward departure. It might grant a departure based on the already familiar terms of probation: compliance programs, internal control improvements, outside corporate monitor, and the submission of periodic reports to the DOJ. But in addition to these forms of remediation, it would grant a further condition of probation-say an increase from a $20 \%$ to a $30 \%$ departure - for the defendant's community service projects.

The projects would fully comport with the DOJ's already existing Guidelines for complying with the MRA. Accordingly, the Guidelines would have a nexus to the violation, would not augment a project that is already receiving federal funding, and the government would play no part in managing the project or its funding. ${ }^{186}$

Following the Guidelines and the environmental precedents, the projects could take a couple different forms. Focusing on prevention through education, the defendant could fund a variety of training programs. These programs would need to be specifically designed to prevent the conduct that gave rise to the violation. They might focus on trade groups, government officials, or business- and law-school students. The defendant might even establish a training center that provided certification in anti-corruption compliance, as recently occurred in environmental enforcement. The training must be specifically designed to prevent the specific harms that the defendant's violation had caused, must occur in the communities where the violation occurred, and must be funded and managed entirely by the defendant (or a third party). ${ }^{187}$

The projects might also seek to correct the harm that resulted from the violation, or prevent similar harm in the future. ${ }^{188}$ In the corruption space, correcting past harms will sometimes prove impossible; in this regard, FCPA violations are essentially different from environmental violations. However, an FCPA defendant would seem uniquely positioned to identify preventative measures that could reduce future harms. This need not be limited to training programs. With the financial support made possible by the supplemental sentence, the defendant could work in conjunction with outside experts (NGOs, consultants, or academics) to write a detailed report. The report could identify the conditions in the host country that gave rise to the violation and develop a series of innovative reforms that would have prevented the violation. These reforms might involve corporate governance, host-country governance, investigative reporting, or enforcement among capital-exporters. They might include the development of enforceable agreements or pacts among competitor companies, the funding of other private-sector initiatives, or more formal legal

186 See supra Part III.B.
187 See supra Part III.B.
188 See supra Part III.B. 
reforms. The defendant, likely working through a third party, could then undertake a sustained and well-funded effort to implement the reforms.

The following section shows how this idea could work out in a specific (though hypothetical) enforcement action. It explains how a supplemental sentence, based on the policies and aims of restorative justice, would comply with the U.S. Constitution, the Miscellaneous Receipts Act, and the Guidelines.

\section{A New Proposal}

This Article has exposed a fundamental paradox, if not a riddle, of extraterritorial white-collar enforcement: we must reach the unreachable, punish the unpunishable, alter the conduct of whole categories of persons who lie beyond our jurisdiction. This riddle exists because deterrence-based enforcement leads to increased levels of host-country bribery. Limited to a one-dimensional focus on manipulating the incentives of those corporate actors subject to its jurisdiction, it creates the conditions in which the criminal conduct of other actors may proliferate. To resolve the paradox, or solve the riddle, criminal punishment must impact, to the extent possible, the behavior of foreign corporations and host-country government officials. The enforcing jurisdiction cannot and will not eliminate criminal conduct by those actors; but it can and should aspire to ensure that its own enforcement efforts do not make the problem worse.

Restorative justice, as applied to multinational corporations, can resolve the riddle in the following way. Imagine a multinational corporation (MNC) with jurisdictional ties to the United States has allegedly committed several FCPA violations in a particular developing country. ${ }^{189}$ To wit, in seeking to gain government approval to enter this market, the MNC flew key officials (and not their spouses) to a lavish offshore location where it hosted several days of "preliminary negotiations." 190 During the visit, the MNC provide expensive gifts - cognac, designer clothing, and luxury box tickets to a highprofile sporting event - to each of these officials. ${ }^{191}$ Finally, the MNC provided jobs to younger relatives of several of the officials. Once these highranking officials approved the MNC's market entry, the MNC then needed to build a number of facilities and sought the cooperation of local officials. It hired a local attorney who specialized in obtaining government approvals. ${ }^{192}$ That attorney coordinated the bribing of various local officials to obtain building permits where the zoning regulations otherwise prohibited

${ }^{189}$ See RESOURCE GuIDE, supra note 85, at 11-12 (explaining the FCPA's jurisdictional provisions).

${ }^{190} I d$. at 24 (discussing "reasonable and bona fide expenditures").

191 See id.

192 See id. at 21-23 (discussing third parties). 
commercial property. So too did the local attorney bribe building inspectors to permit cost-cutting construction measures that violated safety codes.

Once the allegations arose, the MNC followed the standard practice of retaining an outside law firm to conduct an independent investigation and prepared a report detailing its factual findings. ${ }^{193}$ To receive cooperation credit, ${ }^{194}$ the MNC fully cooperated with the DOJ including voluntarily disclosing the investigation report. The defendant enters into a deferred prosecution agreement that stipulates to a number of facts and provides a sentencing range based on the Guidelines' procedures. Imagine that the base fine is $\$ 50$ million, and the sentencing range is $\$ 35$ million to $\$ 65$ million.

But the DOJ grants a 30\% downward departure - as it has already shown itself willing to do ${ }^{195}$ - and requires the defendant to pay a fine of only $\$ 24.5$ million. This downward departure is appropriate because the defendant has agreed to a number of remedial conditions of probation: it has adopted various internal controls, instituted a rigorous compliance program, and accepted an independent corporate monitor. ${ }^{196}$ Additionally, the MNC has volunteered to fund a series of community service projects. These projects will be designed to help the particular local communities where the bribes occurred. ${ }^{197}$

To design the projects, the MNC consulted various representatives of those communities: civic leaders, NGOs, and local businesses. In these consultations, the MNC sought to more fully understand how its conduct impacted the community, which specific harms it caused, the extent to which those harms can now be remedied, and how to prevent similar harms in the future. The MNC also came to more fully understand the local cultural norms surrounding corruption, and discovered that its conduct, which violated the FCPA, fell into three categories: the locals perceived some of the MNC's conduct as highly unusual and offensive (the lavish business trip, for example); some was perceived as quite common, but still offensive (bribing the local officials to violate safety and zoning regulations); and yet some of the conduct was quite common and not particularly offensive (the cognac, clothes, and tickets, for example). The MNC then used this feedback to determine which forms of corruption it should try to remedy and prevent. That is, the local community's definition of corruption, and not the U.S. enforcement agencies', guides the project.

In consultation with internationally recognized anti-corruption experts, the MNC develops three specific projects, proposing a specific timeline and cost for each. The defendant agrees to completely finance the project and manage

\footnotetext{
${ }^{193}$ See $i d$. at 52-56 for an introduction to enforcement procedures.

${ }^{194}$ For a discussion of the alleged "credit" that defendants receive for cooperating with the government's investigation, see Bruce Hinchey, Punishing the Penitent: Disproportionate Fines in Recent FCPA Enforcements and Suggested Improvements, 40 PUB. CONTRACT L.J. 393, 420-21 (2010).

195 See supra Part III.C.

196 See U.S. SENTENCING COMM’N, supra note 8, § 8D1.4.

${ }^{197}$ Id. $\S \S 8 \mathrm{~B} 1.3$, introductory cmt., 8D1.3
} 
the payment. So too does the defendant assume full responsibility for completing the project, likely through hiring a third party, and remains liable for its non-completion. The cost of the proposed community service projects then forms the basis of the additional downward departure: the defendant's fine is reduced by a percentage of the projects' cost, as determined by the prosecutor in her discretion.

The first such project is a small business-loan program for any merchants who can demonstrate that their local business materially suffered as a result of the MNC's bribes. This proposal is designed to remedy certain of the harms that the defendant's conduct caused in disrupting local markets. The second project is a training center for local businesses, attorneys, and government officials, which offers training on how to conduct business with outside companies without drawing them into violation of extraterritorial anti-bribery laws. The center provides a certification that its graduates use to represent to foreign companies that they were well versed in the prevention of bribery violations.

Third, the MNC agrees to write a comprehensive report on its experience of paying bribes in that country. ${ }^{198}$ The report would concede no further facts than were already made public in the deferred prosecution agreement (DPA). Based only on those facts, the report would describe in detail which bribes the MNC paid, and more importantly, why. It would further describe what the MNC discovered about the adverse impact of their conduct on the local community. And unlike the deferred prosecution agreement, the report would then be translated into the local language and systematically publicized across the local media.

This report would serve two purposes. First, it would be a sort of public confession, written in the tone of a mea culpa. The MNC would admit to its illicit payments (as it already has in the DPA) and acknowledge the harm that these bribes caused in the local community.

But in the course of this confession, the report would also describe the conditions in which the MNC felt the bribes were necessary. It would allude to, if not outright detail, the behavior of our two other sets of actors. The first would be the local government officials. The report would indicate where bribes were reasonably thought necessary to obtain the government's approval, either because the official committed outright extortion or because he simply refused to do his job otherwise. Second, the report could also explain the conduct of local and foreign competitor companies. These competitors might be paying bribes to obtain an advantage, such that the defendant felt it could not compete without doing the same, or the local competitors might routinely engage in this conduct, and the government either does not care and expected

198 One of the "Recommended Conditions of Probation" in the Sentencing Guidelines Manual is that the organization "at its expense" and in a specified "format and media" may "publicize the nature of the offense committed, the fact of conviction, the nature of the punishment imposed, and the steps that will be taken to prevent the recurrence of similar offenses." Id. § 8D1.4(a). 
it or even demanded the same. The mea culpa, then, would simultaneously expose the extent of the problem that existed prior to the defendant's investment in that market.

The defendant MNC would design a plan to publicize this report in two ways. First, and as indicated above, it would distribute the report across the local media. Second, it would deliver the report to various international organizations, particularly those charged with overseeing the implementation of the various anti-corruption agreements: the United Nations Office of Drugs and Crime (custodian of the UN Convention Against Corruption) ${ }^{199}$ and the Organization for Economic Cooperation and Development (custodian of the OECD Convention on Combating Bribery of Foreign Public Officials), ${ }^{200}$ as well as the major relevant NGOs such as Transparency International. ${ }^{201}$

This report, thus publicized, and in combination with the training facility, would begin to improve the host-country conditions that precipitate bribery in several ways. First, host-country officials would be educated in briberyreduction strategies.

This training would help, but of course these officials have material incentives to continue accepting bribes. Where education and good will cannot reduce the problem, the report steps in, and provides the second mechanism for improving host-country conditions. In publicizing the company's report of systemic bribery across the local and national media, local political pressures are exerted on the government to effect reforms; consider Brazil or China as powerful recent examples of this phenomenon. ${ }^{202}$

Third, in the hands of international organizations, the report can trigger the levers of international diplomacy, exerting pressure on two kinds of countries. Of course, where the host country has proven to be systemically complicit in international bribery schemes, organizations will pressure the country to more meaningfully enforce domestic bribery prohibitions. But so too will these levers be brought to bear on the other capital-exporting nations whose companies are participating in the host-country's bribery. That is, the nonenforcing capital-exporting jurisdictions, whose companies pay bribes overseas without fear of punishment, can be pressured to enact and enforce extraterritorial bribery prohibitions. This is the story of the OECD's AntiBribery Convention, in which recent years have shown a steady increase in enforcement by member nations largely in response to the pressure of fellow members. Germany, for example, which once publicly mocked the United States for enacting the FCPA, has now become among the OECD's leading

199 United Nations Convention Against Corruption, G.A. Res. 58/4, U.N. Doc. A/58/4 (Oct. 31, 2003).

200 OECD Anti-Bribery Convention, supra note 58.

201 See TRANSPARENCY INTERNATIONAL, http://www.transparency.org/ (last visited Mar. 25, 2015), archived at http://perma.cc/F9N9-NT45.

202 See, e.g., Taking to the Streets, ECONOMIST (June 22, 2013), http://www.economist.com/news/americas/21579857-bubbling-anger-about-high-pricescorruption-and-poor-public-services-boils-over, archived at http://perma.cc/5WJC-AFKU. 
enforcers of its similar law. ${ }^{203}$ Through these levers, those companies that were once substitute investors now become reluctant bribe payers. As the number of jurisdictions enforcing an extraterritorial prohibition increases, and the number of reluctant MNC bribe payers increases, rates of host-country bribery decline.

Admittedly, these methods would only make a minor dent in the prevalence of host-country bribery. They would constitute but a small part of a much larger and more complex strategy for reducing such bribery. But recall our aim: ${ }^{204}$ to reduce host-country bribery by somewhere between $4-11 \%$. Were that mark achieved, the enforcing country would have accomplished its goal: to enforce an extraterritorial prohibition that actually improved the social conditions of both the actual and prospective victims of multinational corporate crime.

This accomplishment, at once modest and transformative, is made possible by the uniquely three-dimensional approach of restorative justice. ${ }^{205}$ The defendant does not merely pay a fine; it is forced to confront the victims of its crime. Through the consultations with community leaders, the MNC is confronted by, and listens to, the victims (and their representatives). ${ }^{206}$ In then deliberately broadcasting across the local media an admission of its guilt, the MNC admits to its wrongdoing and acknowledges the harm it caused. Perpetrator and victim thus hear each other's narratives, seeking understanding and reconciliation. ${ }^{207}$ The defendant then voluntarily participates in the sentencing by designing community service projects and taking full responsibility for their cost and completion. ${ }^{208}$ The community has thus achieved a fuller understanding of its past, and its future, and the norm transgression is affirmed. ${ }^{209}$

The victims are restored both through remediation (such as the loan program) and prevention (the training center and the political pressure to implement reforms). The victim becomes empowered: its own account of the crimes committed and the harms caused, informed by the community's own cultural norms and social experience, forms the basis of the sentence. To the extent that the defendant has thus repaired its reputation and restored a measure of good will in the community, it can resume its business practices. Now compliant with anti-bribery laws, it reintegrates into the very community it once knowingly victimized and repairs the social processes it once damaged.

${ }^{203}$ For a historical account of Germany's compliance with anti-bribery conventions, see, for example, Germany - OECD Anti-Bribery Convention, OECD, http://www.oecd.org/daf/anti-bribery/germany-oecdanti-briberyconvention.htm (last visited Mar. 5, 2015), archived at http://perma.cc/M3JS-TFV2.

204 See supra Part III.C.

205 See supra Part IV.A.

206 See BRAITHWAITE, supra note 7, at 11.

${ }^{207}$ Menkel-Meadow, supra note 90, at 164.

208 See E.S.C. Res. 2002/12, supra note 97, at I.2.

${ }^{209}$ See Walgrave, supra note 96, at 61-62. 
However, the defendant's overall financial penalty is no less than a traditional fine, and can actually be greater: the defendant's fine reduction may be less than the full cost of the projects, as determined in the prosecutor's discretion. The good will benefits to the corporation thus do not render the sentence's deterrent value lower than a conventional fine. ${ }^{210}$ Moreover, care will be taken to ensure that the defendant corporation does not benefit in any illicit way from the project; the project will likely be managed in large part by a neutral third party, and the defendant may be required to submit periodic reports to the DOJ. The corporation and the third party can likewise manage the project with sufficient care to ensure that the host country's government or third parties do not embezzle the money. The corporation will use its ample resources to monitor the project and ensure that the money never passes into any government official's hands, whether in the United States or the host country.

This proposal is not without its drawbacks. The possibility that these anticorruption measures could become corrupted is of course omnipresent. Some may argue that any gains from these projects will be offset by the loss in revenue to the U.S. treasury. And yet others may simply maintain that the United States has historically concerned itself too much, and not too little, with "reforming" countries in transition. Finally, some will note that crime is a vast, complex, and deeply-entrenched problem which the developed world's efforts, no matter how innovative and well-meaning, cannot solve.

The latter point, at least, is certainly true. We will not eliminate bribery, or corporate crime, whether overseas or within our own jurisdictions. Nor will we eliminate murder; but this is hardly an argument against its prohibition. The proposal developed here has a much more modest goal: to ensure that our efforts to reduce overseas crime make the situation incrementally better or, at very least, do not make the problem worse.

\section{CONCLUSION}

Two recent U.S. Supreme Court cases famously restricted laws that (once) governed overseas corporate conduct: Kiobel v. Royal Dutch Petroleum Co. ${ }^{211}$ (concerning the Alien Tort Statute), and Morrison v. National Australian Bank Ltd. ${ }^{212}$ (concerning Section 10b of the Securities Exchange Act of 1934). But rumors of the death of extraterritorial application are greatly exaggerated. Federal law continues to govern-legitimately-U.S. corporations overseas in such diverse areas as employment discrimination, ${ }^{213}$ antitrust, ${ }^{214}$ trade and

210 Duff, supra note 103 , at 43 .

${ }^{211}$ Kiobel v. Royal Dutch Petroleum Co., 133 S.Ct. 1659 (2013).

212 Morrison v. Nat'l Australian Bank Ltd., 561 U.S. 247 (2010).

213 Age Discrimination in Employment Act, 29 U.S.C. $\$ \S 621-634$ (2012); Civil Rights Act of 1964, tit. VII, 42 U.S.C. § 2000e(f) (2012); Americans with Disabilities Act, 42 U.S.C. $\S 12101-12213$ (2012), as amended by Civil Rights Act of 1991, Pub. L. No. 102-166, § 109(b), 105 Stat. 1071. The U.S. Supreme Court had invoked the presumption 
economic sanctions, ${ }^{215}$ money laundering, ${ }^{216}$ and of course, bribery. ${ }^{217}$ Supreme Court jurisprudence notwithstanding, Congress's constitutional authority to regulate foreign commerce is indeed alive and well. ${ }^{218}$

And we should expect Congress to exercise that authority with increasing, rather than decreasing frequency, as U.S. companies increasingly invest in foreign markets. Where those markets' legal regimes remain nascent, the capital-exporting country bears a substantial burden. Whether foreign investment in developing countries inures to the latter's good, or ill, depends in large measure on the careful enforcement of extraterritorial corporate criminal law.

This Article sounds a note both cautious and optimistic. Familiar modes of criminal punishment - general deterrence guided by the utility calculations and incentive adjustments of law and economics - will not carry the day. In any area of corporate conduct that host countries and other capital exporters fail to effectively regulate, our own deterrence efforts will frequently make matters worse. But the solution, perhaps surprisingly, has been there all along. Restorative justice provides an alternative paradigm of criminal punishment with already well-established authorization under the U.S. Constitution, the Guidelines, and a decades-old DOJ practice. It could restore overseas victims through both remediation and prevention, and would help ensure that our foreign investment promotes, rather than impedes, the growth of sustainable institutions. The remedy this Article proposes is thus already completely legal under federal law. It requires no more for its immediate adoption than our government's informed resolve.

against territoriality to hold that Title VII did not so apply. EEOC v. Arabian Am. Oil Co., 499 U.S. 244 (1991). That same year, Congress responded by amending both Title VII and the ADA to expressly apply extraterritorially. See Spalding, The Irony, supra note 12, at 383-85.

${ }^{214}$ Sherman Act, 15 U.S.C. $\S \S 1-7$ (2012); Clayton Act, 15 U.S.C. $\S \S 12-27$ (2012).

215 The two principal statutes are the International Emergency Economic Powers Act, Pub. L. No. 95-223, 50 U.S.C. $\S \S 1701-1707$, and the Trading with the Enemy Act, 50 App. U.S.C.A. $\S \S 1-39,41-44$ (West 2014).

${ }^{216}$ Money Laundering Control Act of 1986, 18 U.S.C. $\S \S 1956-1957$ (2012); Bank Secrecy Act, 21 U.S.C. $\S \S 1951-1959,31$ U.S.C. $\S \S 5311-5314$, 5316-5332 (2012).

${ }^{217}$ Foreign Corrupt Practices Act of 1977 (FCPA), Pub. L. No. 95-213, 91 Stat. 1494, amended by Omnibus Trade and Competitiveness Act of 1988, Pub. L. No. 100-418, 102 Stat. 1107 and by International Anti-Bribery and Fair Competition Act of 1998, Pub. L. No. 105-366, 112 Stat. 3302 (codified as amended in scattered sections of 15 U.S.C.).

${ }^{218}$ U.S. Const. art. I, § 8, cl. 3. See generally Anthony J. Colangelo, The Foreign Commerce Clause, 96 VA. L. REV. 949 (2010) (discussing the scope of congressional authority to regulate foreign commerce). 